\title{
The Atlas-East Variscan -Elbe shear system and its role in the formation of the pull-apart Late Palaeozoic basins
}

\author{
Franco Marco Elter ${ }^{1} \cdot$ Laura Gaggero $^{1}\left[\right.$ [ $\cdot$ Federico Mantovani ${ }^{1} \cdot$ Enrico Pandeli $^{2,3} \cdot$ Luca Giacomo Costamagna $^{4}$
}

Received: 11 March 2019 / Accepted: 2 February 2020

(c) Geologische Vereinigung e.V. (GV) 2020

\begin{abstract}
The Variscan orogeny occurred as a result of the Late Devonian to Late Carboniferous collision and accretion of Gondwanaderived microcontinents and continental masses with those of Laurussia. The irregular boundaries of the colliding continents caused isochronous transpressional and transtensional tectonics, accompanied by a complex pattern of intracontinental shear zones at the scale of the southern European Variscides. These shear zones and their configuration controlled the subsequent evolution of Permian to Middle Triassic paleogeography. The geographic distribution, from Morocco to the Eastern Alps, of the Late Carboniferous-Permian up to Triassic basins, most of which are considered as pull-apart basins, was related with the development of the Late Palaeozoic intracontinental shear network. Our analysis of the stratigraphic, tectonic and volcanic features of the Late Carboniferous/Permian continental basins across the Laurussia/Gondwana boundary reveals the role of the East Variscan Shear Zone during this time as a precursory lineament for the development of the Permian to Triassic rifting of Pangaea and the following opening of oceanic basins (e.g., the Neothetyan Ocean).
\end{abstract}

Keywords Late Palaeozoic shear network · Carboniferous-Permian basin evolution · Mediterranean and Central Europe · Alpine Wilson cycle

\section{Introduction}

The Late Permian to Tertiary orogenic Wilson cycle that affected the Pangaea continent evolved through rifting, breakup and opening of an oceanic basin, followed by its closure and by the accretion of displaced terranes to form new continents (Dewey 1988; Vai 2003; Gutiérrez-Alonso et al. 2004, 2008). Weil et al. (2013) resume the origin of the Variscan orogen in the closing of at least two-and possibly four-oceans between Laurentia, Baltica, and Gondwana, and interposed micro-continents, during the Palaeozoic

Laura Gaggero

laura.gaggero@unige.it

1 Department of Earth, Environment and Life Sciences, University of Genoa, Corso Europa 26, 16132 Genoa, Italy

2 Department of Earth Sciences, University of Florence, Via La Pira 25, 50121 Florence, Italy

3 Institute of Geosciences and Earth Resources, Section of Florence, CNR (National Research Council of Italy), Via G. La Pira 4, 50121 Florence, Italy

4 Department of Earth Sciences, University of Cagliari, Via Trentino 51, 09127 Cagliari, Italy amalgamation of the Pangea supercontinent. Afterwards, late, to post-orogenic modification of the Western Europe Variscan Belt shaped the four complete arcs from Poland to Brittany, and then across the Bay of Biscay (Cantabrian Sea) into Iberia, where they are truncated by the Betic Alpine front in southern Spain (Weil et al. 2013).

Four different processes have been proposed to explain Pangaea rifting before the onset of the Early Jurassic breakup: (1) post-Variscan-Alleghenian orogenic collapse (Malavielle et al. 1990); (2) dispersal above a mantle superplume (Veevers 2005); (3) a combination of different mechanisms (Hynes 1990); and (4) self-subduction of the Pangaean global plate (Gutiérrez-Alonso et al. 2008).

Bonin et al. (1998) identified three major episodes for an orogenic cycle: (a) intracontinental rifting and plate divergence, followed by oceanic basin opening and ending with the onset of subduction along active margins; (b) plate convergence (due to ocean/ocean and/or ocean/continent subduction), oceanic basin closure and continent/continent collision associated with wrench and thrust tectonics; and (c) dominantly ensialic accretion of continental blocks or terranes by docking and/or hyper-collision, together with uplift and transcurrent fault tectonics, generating transpressional 
and transtensional regimes. The geodynamic settings of the three distinct episodes have been driven by the contrasting rheologies of the lithosphere and asthenosphere (Bonin et al. 1998; Ziegler and Stampfli 2001).

The Variscan orogeny is widely interpreted as a result of the Carboniferous collision and accretion of Gondwanaderived microcontinents and continental masses with those of Laurussia (Gutiérrez-Alonso et al. 2008; Padovano et al. 2014). The irregular boundaries of the colliding plates generated coeval transpressional and transtensional tectonics, accompanied by a complex pattern of intracontinental shear zones at the scale of the southern European Variscides (Arthaud and Matte 1977; Neubauer and Handler 2000; Gutiérrez-Alonso et al. 2004, 2008; Martínez Catalán 2011; Padovano et al. 2011, 2014; Dias et al. 2017; Ballèvre et al. 2018; Fig. 1). In particular, the broad-scale shear network is characterised by activity on several main intracontinental strike-slip shear zones. In the northern region of Pangaea, these shear zones include the Appalachian Minas Fault Zone (Murphy et al. 2011), the South and
North Armorican Shear Zones (Tartese et al. 2012) and the Elbe Shear Zone (Schenk et al. 2002; Pressler et al. 2007), and in the southern region include the Atlas Shear System (Bouaziz et al. 2002, e.g., Fig. 1). This shear network was subsequently partially transposed by the Alpine orogeny to the east (Dinarides-Hellenides). Nevertheless, relics of Late Carboniferous shearing can be recognised in the Tisia and Moesia areas (Dornsiepen et al. 2001; Pamic and Jurkovic 2002; Cortesogno et al. 2004a, b; Carrigan et al. 2006), in the Alps (Schaltegger and Brack 2007) and in the Northern Apennines (Rau 1993; Pandeli 2002; Padovano et al. 2011). In the peri-Gondwana-derived microcontinents (e.g., Iberia and France), two important intracontinental strike-slip shear zones can be also identified: the sinistral antithetic Coimbra-Cordoba Shear Zone (Pereira et al. 2010) and the dextral North Pyrenees Shear Zone (Arche and Lopez-Gomez 2005; Gretter et al. 2015; Fig. 1). The western boundary between the peri-Gondwana-derived microcontinents and Gondwana is conversely represented by the East Variscan Shear Zone (EVSZ, e.g., Fig. 1) (Padovano et al. 2011, 2014).

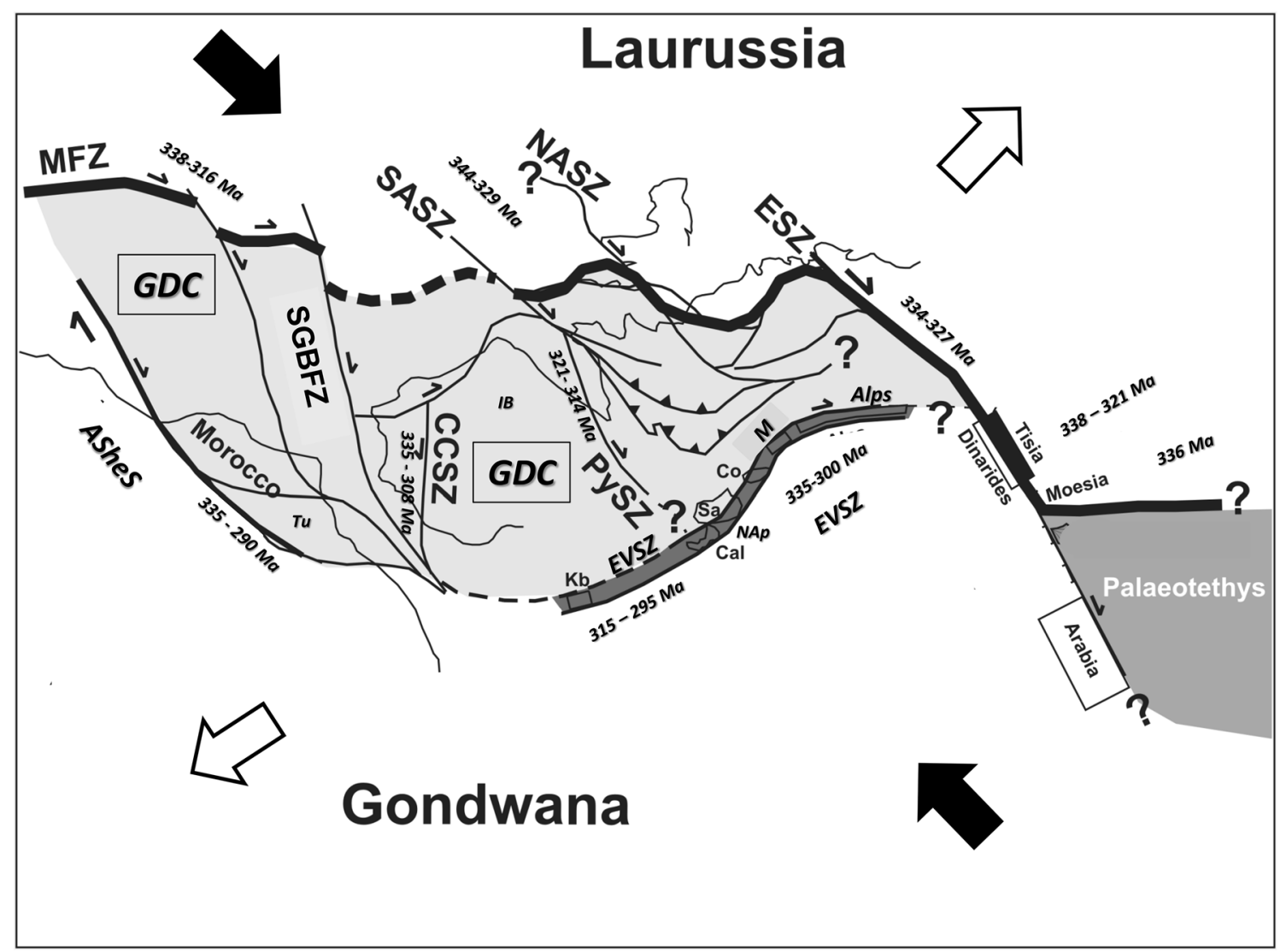

Fig. 1 Major intracontinental shear zones active during the Late Carboniferous and their ages of shearing (see in the text). GDC Gondwana derived continents, ASheS Atlas shear system, SGBFZ Southern Grand Banks Fault Zone (dextral), EVSZ East Variscan Shear Zone (dextral), CCSZ Coimbra-Cordoba Shear Zone (sinistral), PySZ North Pyrenees Shear Zone (dextral), MFZ Minas Fault
Zone (dextral), SASZ South Armorican Shear Zone (dextral), NASZ North Armorican Shear Zone (dextral), ESZ Elbe Shear Zone (dextral), Tu Tunisia, IB Iberia, Kb Kabyles, Sa Sardinia, Cal Calabria, NAp Northern-Apennines, Co Corse, MT.M Maures ( modified from Padovano et al. 2011). Black arrows: Late Carboniferous shortening. White arrows: Late Carboniferous extension 
In this paper, we revised the structural framework of the EVSZ and of other intracontinental shear zones in different segments of the Variscan belt of Europe and of the other peri-Mediterranean countries (from Morocco to the Balkan peninsula), focusing on the stratigraphic, tectonic and volcanic features of the associated Late Carboniferous-Late Permian (pull-apart) basins (rhomb-graben-or domino-like pull-apart structures; Hatcher 1995).

This integrated analysis allowed us to (1) define the main tectono-sedimentary and magmatic stages as having occurred during the complex Carboniferous to Triassic shearing events in the analysed area and (2) speculate whether these structures might be prodrome to those developed in the following Alpine Wilson cycle that dismembered Pangaea.

\section{The East Variscan Shear Zone}

The EVSZ (Padovano et al. 2011, 2014, Fig. 1) was characterised by NW-SE shortening during the Late Carboniferous (Neubauer and Handler 2000; Bouaziz et al. 2002; Cassinis et al. 2012; Padovano et al. 2014). This was one of the largest Variscan intracontinental dextral strike-slip shear zones and extended from Slovenia through the Alps to North Africa. The EVSZ was active between $325 \pm 1.3 \mathrm{Ma}(\mathrm{U}-\mathrm{Pb}$ radiometric age on monazite) and $315 \pm 1.3 \mathrm{Ma}$ (U-Pb radiometric age on zircon) (Carosi et al. 2012; Padovano et al. 2014). Therefore, the EVSZ was connected in both time and space with the Atlas Shear System and the Elbe Shear Zone (Fig. 1).

The width of the EVSZ varies from a few kilometres (e.g., Emosson Lake, Aiguilles Rouges-Mt. Blanc massifs, in Genier et al. 2008; and in the Argentera Massif in Corsini et al. 2004) to $40 \mathrm{~km}$ (Sardinian Massif, in Elter et al. 2010; Padovano et al. 2014). This dextral shear zone shows an S-shape in plan view (Elter et al. 2011, Fig. 1), varying from an E-W trend in the eastern Central Alps to a N-S/NE-SW trend in the Western Alps/Corsica/Sardinia/Calabria and Tunisia.

A complex geological evolution can be locally pointed out for the EVSZ. In NE Sardinia (see data from HGMC in Elter et al. 2010; Padovano et al. 2011, 2014), the EVSZ underwent two episodes of shearing: an older dextral-shear stage, dated at $325 \pm 1.3 \mathrm{Ma}$ (U-Pb radiometric age on monazite), characterised by amphibolite-facies metamorphism, and a younger local sinistral-shear stage with greenschist-facies metamorphism imprint, which was contemporaneous with the synkinematic emplacement of peraluminous granitoid rocks, dated between $318 \pm 3$ and $315 \pm 2 \mathrm{Ma}$ (U-Pb radiometric age on zircon; Padovano et al. 2014). Furthermore, two different metamorphic zones of amphibolite-facies grade are distinguished in the EVSZ: an inner zone that was overprinted under the stability field of sillimanite and an external zone within the stability field of kyanite (Elter et al. 2010).

The EVSZ evolved simultaneously with other intracontinental shear zones between 335-300 Ma (e.g., Fig. 1 and references in Padovano et al. 2011, 2014), including the dextral Southern Grand Banks Fault Zone (SGBFZ), the sinistral Coimbra-Cordoba Shear Zone (CCSZ), the dextral Pyrenees Shear Zone (PySZ), the dextral Minas Fault Zone (MFZ), the dextral South Armorican Shear Zone (SASZ), the dextral North Armorican Shear Zone (NASZ) and the dextral Elbe Shear Zone (ESZ). The exhumation of high-temperature metamorphic rocks was driven by the formation of a coeval shallow restraining bend that involved the telescoping of isotherms (Padovano et al. 2011, 2014, and references therein) producing melts and mylonitic foliations, within the older dextral transpressive shear regime, as shown by field evidence and finite strain analysis in NE Sardinia (Elter et al. 2010).

The NW-SE Carboniferous shortening direction (Neubauer and Handler 2000; Bouaziz et al. 2002; Cassinis et al. 2012; Padovano et al. 2014) continued also in the Early Permian age (Stampfli et al. 2000; Stampfli and Borel 2002; Beltrando et al. 2007; Bergerat et al. 2007; Muttoni et al. 2009; Catalan et al. 2011; Aubele et al. 2012; Cassinis et al. 2012; Bachtadse et al. 2018).

Pohl et al. (2018) and Zanchi et al. (2019) evidenced pure extension in SSE-NNW direction instead of Permian dextral strike slip in the Central/Southern Alps. Zanchi et al. (2019) inferred deformations at shallow crustal level which occurred during the Early Permian along high-angle normal faults soling into the Low Angle Normal Faults, forming the northern boundary of the Orobic Basin. Pohl et al. (2018), however, highlighted the syn-kinematic emplacement of the Permian Val Biandino Quartz Diorite (287 Ma) with a $\mathrm{D}_{2}$ mylonitic top-to-SE component of shear.

Moreover, Cassinis et al. (2012), Berra et al. (2014), described the Permian basins with a NE-SW direction of extension, possibly coeval with an E-W dextral sense of shear.

Anyway, the Late Carboniferous-Lower Permian dextral motion of Laurussia relative to Gondwana could have caused the fragmentation of the northern Gondwana margin into several crustal blocks (Fig. 2; Aubele et al. 2012; Padovano et al. 2014), designated as Gondwana Derived Continents (GDC). The GDC crustal blocks are subject to differential rotations due to a set of discrete continental shear zones (Aubele et al. 2012). 


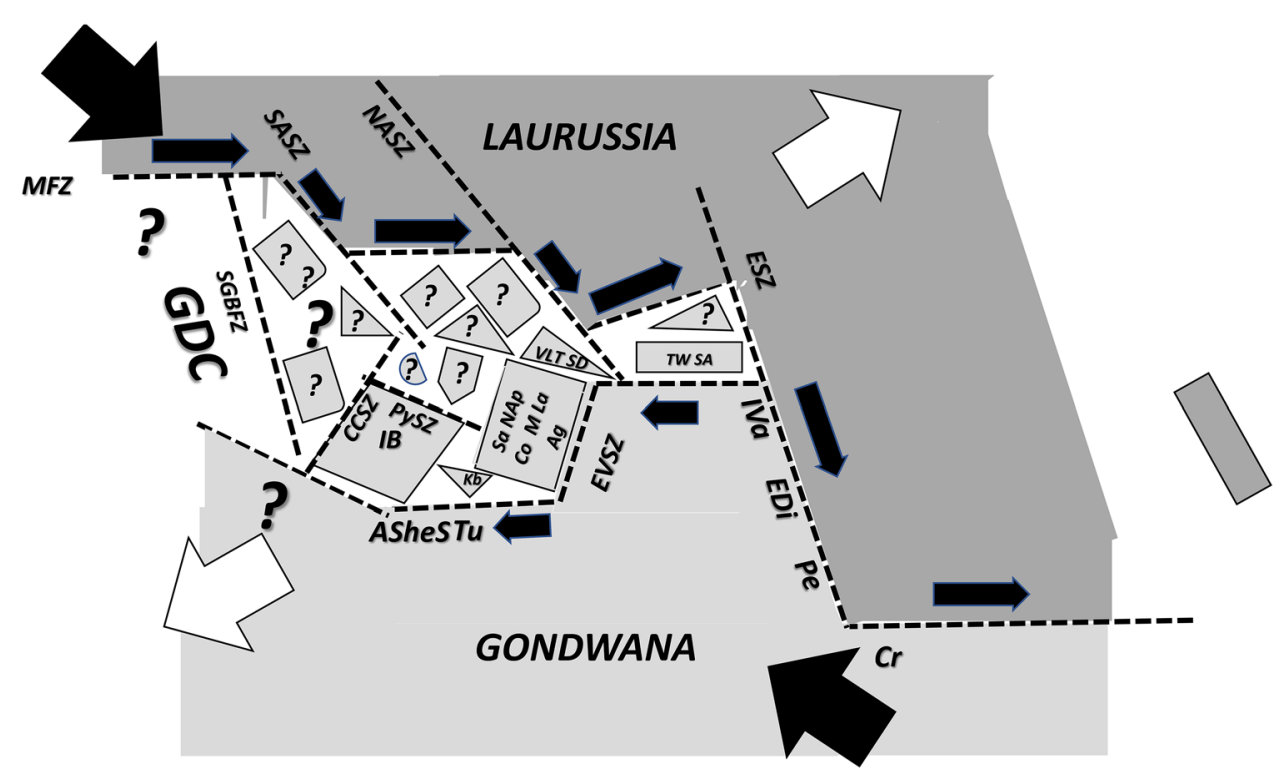

Fig. 2 The Late Carboniferous-Early Permian dextral shearing could have taken up the fragmentation of the northern Gondwana margin involving the Gondwana Derived Continents (GDC). ASheS Atlas shear system, $T u$ Tunisia, $I B$ Iberia, $K b$ Kabyles, $S a$ Sardinia, $N A p$ Northern Apennines, Co Corse, $M$ Maures, La Ligurian Alps, Ag Argentera, VLT Versoyen-La Thuile Basin, SD Salvan-Dorénaz Basin, $T W$ Tauern Window Basin, $S A$ Southern Alps basins, IVa Idrjica Valley basin, EDi External Dinarides basin, Pe Pelopon-

\section{Tectono-sedimentary evolution of Carboniferous-Permian to Triassic basins along EVSZ}

The location of the EVSZ with respect to other main tectono-structural elements not only played a fundamental role during the Late Carboniferous geodynamics but also had major control over the subsequent evolution of Permian to Middle Triassic paleogeography (e.g., Ballèvre et al. 2018). The distribution of Late Carboniferous-Permian basins, from Morocco to the Eastern Alps, has generally been related with the development of this shear network, and therefore the basins are considered as pull-apart, in particular rhomb-graben-like or domino-like pull-apart structures (Hatcher 1995). In this regard, many Late Carboniferous to Early Permian pull-apart basins in the Southern Alps are related with the general dextral megashear (e.g., Cassinis et al. 2018; Ballèvre et al. 2018). Moreover, at c. $275 \mathrm{Ma}$, their sedimentation was interrupted for $c$. 10-15 My, leading to the development of a "mid-Permian" unconformity (Deroin and Bonin 2003; Schaltegger and Brack 2007). This main unconformity was related with (1) the post-collisional collapse of the Variscan orogen (Henk et al. 1997), (2) the post-tectonic extension that marks the beginning of the Alpine rifting and that was connected to the opening of the NeoTethys (Cassinis et al. 2018) and (3) nese basin, $C r$ Crete basin, $M F Z$ Minas Fault Zone, SGBFZ Southern Grand Banks Fault, EVSZ East Variscan Shear Zone, SASZ South Armorican Shear Zone, NASZ North Armorican Shear Zone, CCSZ Coimbra-Cordoba Shear Zone (sinistral), PySZ Pyrenees Shear Zone, black arrows: Upper Carboniferous-Early Permian direction of shortening; white arrows: Upper Carboniferous-Early Permian direction of extension (from Aubele et al. 2012, modified); areas with question marks: unknown terrains of GDC

the revival of large-scale strike-slip tectonics and erosion, locally attaining crustal thinning, upwelling, and partial melting of mantle, followed by the advection of melts and crustal heating (Prost and Becq-Giraudon 1989; Handy and Zingg 1991; Cadel et al. 1996; Schaltegger and Brack 2007; Marotta and Spalla 2007).

In the Northern Apennines, Rau (1993) and Pandeli (2002) identified several Late Carboniferous-Permian to Late Triassic sedimentary cycles. The unconformities between the sedimentary sequences have been related with tectonic events (Asturian, Saalian, Palatine, Late Scythian and/or Early Anisian and Late Ladinian events) and record repeated strong extensional or transtensional/transpressional activity within the Tuscan mobile belt between the Late Carboniferous and Late Ladinian periods, when Alpidic regional rifting finally began. Taking into account the change in shortening direction from NW-SE to W-E (e.g., Timmerman 2004), the Late Carboniferous shear network was probably active up until the Ladinian period, consistent with the evidence for the Southern Alps (Schaltegger and Brack 2007).

The tectono-sedimentary development and igneous evolution of Late Palaeozoic basins in the areas of interest are described and synthesised below (for details, see references). 


\section{Permian basins in Tunisia}

In Tunisia (Figs. 3, 4), the Tebaga of the Medenine Basin (Raulin et al. 2011) trends E-W and represents an important outcrop of Permian marine rocks in Africa. This structure resulted from large-scale block tilting controlled by E-W faults (in particular the Aziza Fault, with a NE-SW direction of extension, as in the Atlas Shear System) extending along the Jeffara Plain (Raulin et al. 2011). The Upper Permian succession, unconformably lying on Early Permian or older successions, is characterised by four sedimentary sequences: (a) a basal unit represented by sandy, shale deposits with marine fauna; (b) a unit of carbonate biohermal sediments; (c) a shale unit; and (d) an uppermost unit represented by sandy, shale deposits (Khessibi 1985; Kilani-Mazraoui 1990). The last authors pointed to an important unconformity present at the Early Scythian level and marked by the absence of part of both the Upper Permian and Lower Scythian.

\section{Permian basins in peri-Gondwana-derived microcontinents}

\section{Iberia}

The Iberian Peninsula recorded the break-up of Pangea by a Permian Triassic rifting stage that originated the Pyrenean, Iberian, Catalan, Ebro and Betic basins, and the basins located in the present-day Balearic Islands (Lopez-Gòmez et al. 2019). The evolution went through an early phase characterised by large-scale transtensional and extensional regime, an initial tectonic step corresponding to basin definition, followed by a mature step characterised by thermal

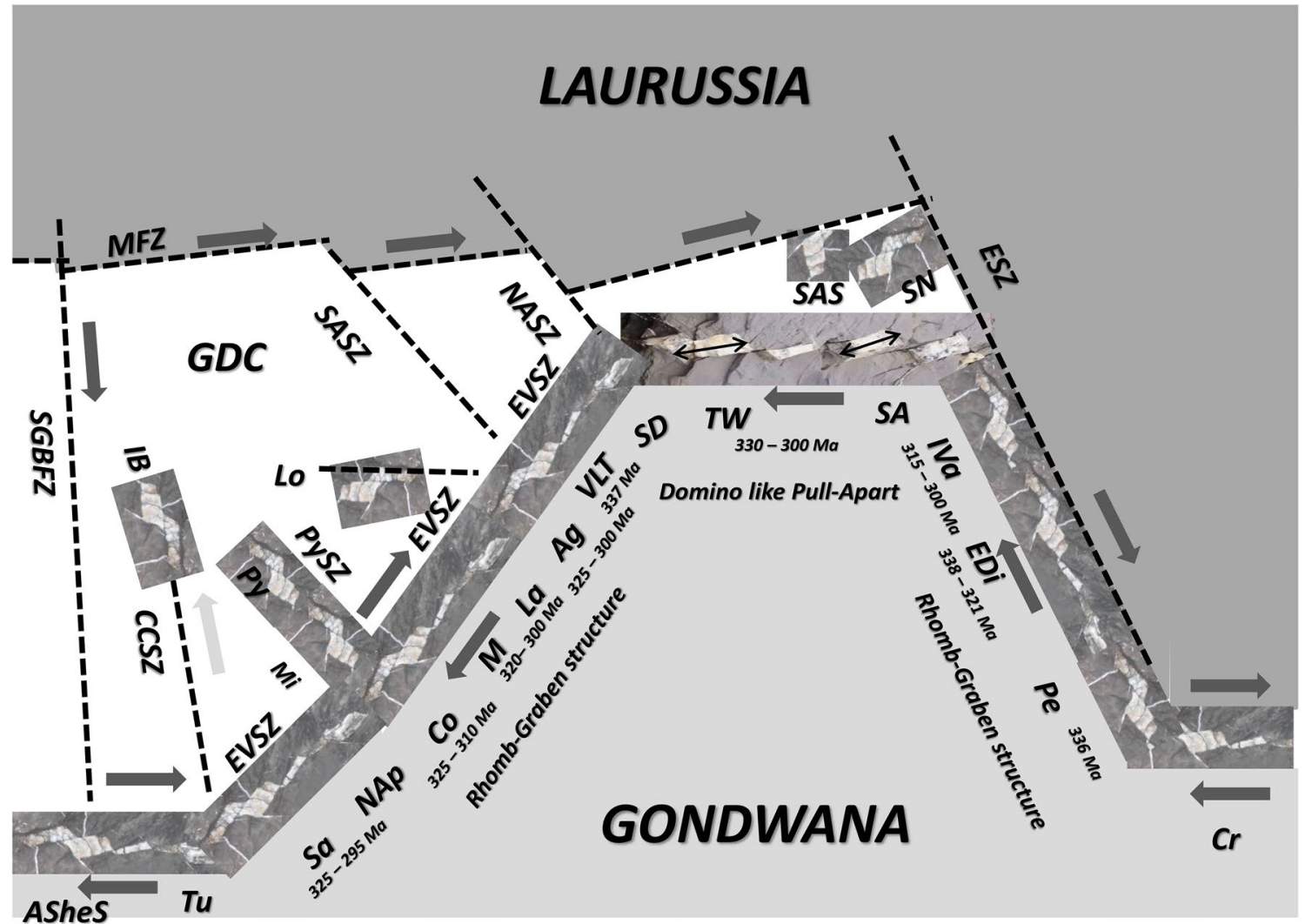

Rhomb-Graben structure

Fig. 3 Distribution of Permian basins (not to scale). GDC Gondwana derived continents, ASheS Atlas Shear System, Tu Tunisia, IB Central Iberia basins, $M i$ Minorca basin, $P y$ Pyrenees basins, $S a$ Sardinian basins, NAp Northern Apennines basins, Co Corsican basin, $M$ Maures basin, La Ligurian Alps basin, Ag Argentera basin, VLT Versoyen-La Thuile basin, SD Salvan-Dorénaz basin, $T W$ Tauern window basin, SA Southern Alps basin, SN Saar-Nahe basin, SAS Saxonian Graben, IVa Idrjica Valley basin, EDi External Dinarides basin, $\mathrm{Pe}$ Peloponnese basin, $\mathrm{Cr}$ Crete basin, SGBFZ Southern Grand Banks
Fault (dextral), EVSZ East Variscan Shear Zone (dextral), CCSZ Coimbra-Cordoba Shear Zone (sinistral), PySZ Pyrenees Shear Zone (dextral), MFZ Minas Fault Zone (dextral), SASZ South Armorican Shear Zone (dextral), NASZ North Armorican Shear Zone (dextral), ESZ Elbe Shear Zone (dextral). Photograph: schematic image of rhomb-graben structure and domino like pull-apart structures at the mesoscale in the Cretaceous Antola Unit (Northern Apennines, Italy); 335-300 Ma: ages of shearing (after Padovano et al. 2011) 


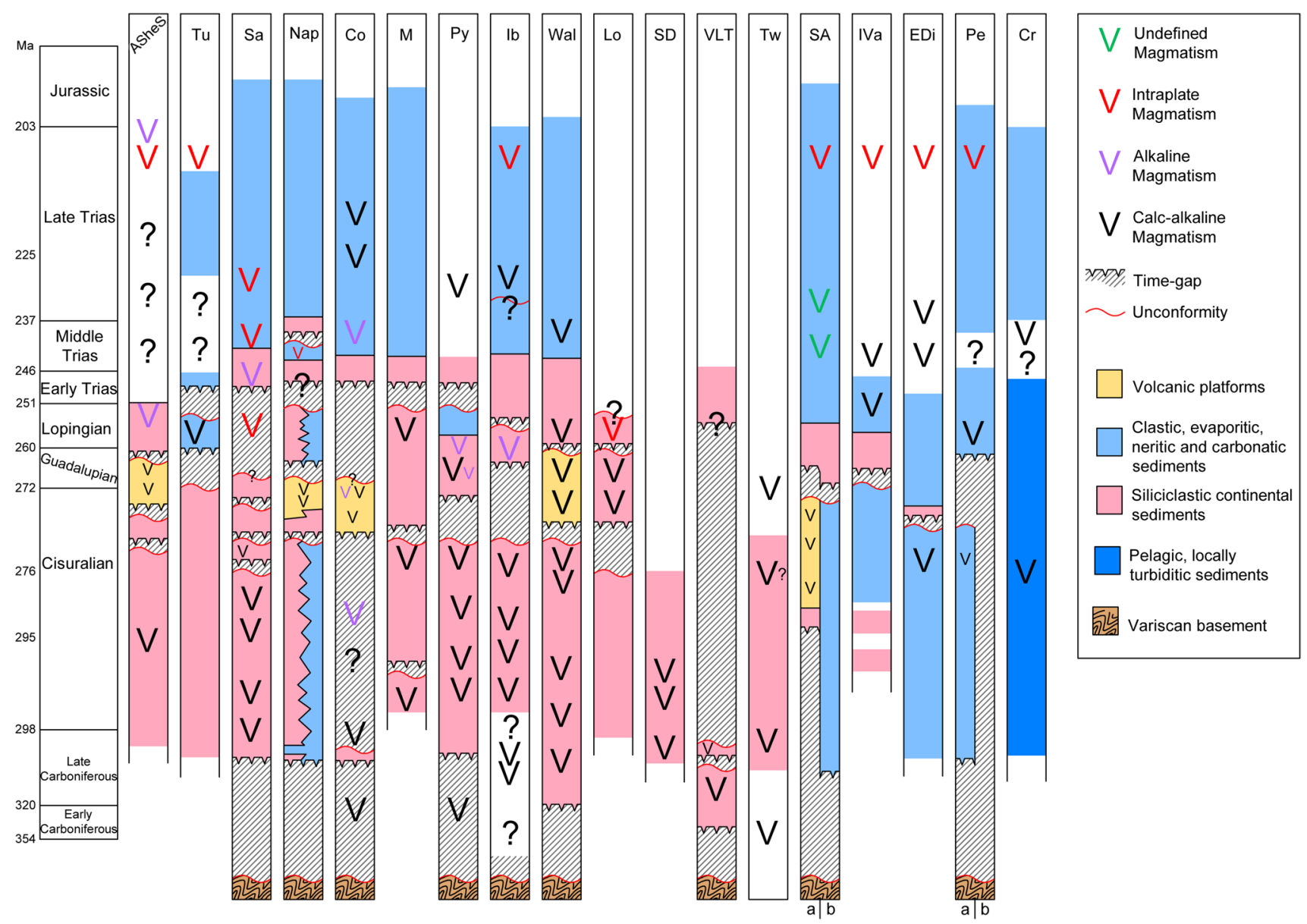

Fig. 4 Synthesis of the stratigraphic-sedimentary features of some Late Carboniferous-Permian basins in the considered areas' Permian basins. ASheS Atlas shear system, Tu Tunisia, $\mathrm{Sa}$ Sardinian basin, $N A p$ Northern Apennines basins, Co Corsican basin, $M$ Maures basin, Py Pyrenees basin, Ib Central Iberia basin, Wal Western Alps (includ- ing the Argentera and Ligurian Basins), Lo Lodève basin, SD SalvanDorénaz basin, VLT Versoyen-La Thuile basin, $T W$ Tauern Window basin, SA Southern Alps basin, a-Dolomites, b- Carnic Alps; IVa Idrjica Valley basin, EDi External Dinarides basin, Pe Peloponnese basin, a- Plattenkalk Group, b- Tyros Group, $\mathrm{Cr}$ Crete basin subsidence under extensional regime and lithospheric breakup into microplates.

The collapse and dismantling of the Variscan belt were associated with a transcurrent component that produced the Pyreneean basin in Early Permian times. The numerous basins were infilled by alluvial fan slope breccias, fluviolacustrine sediments and volcanic_-volcaniclastic products, decreasing and ceasing at the mid-Permian. In the Pyrenees and eastern Iberian plate, following the mid-Permian event, the transtensional regime led to the development of symmetric basins bounded by lystric faults, probably as the response to dextral strike-slip movements at the margins of the Iberian Microplate and the crustal collapse of the overthickened roots of the Variscan orogen (Lopez-Gòmez et al. 2019).

The Iberian Basin developed on the Variscan basement comprising Ordovician-Silurian slates and quartzites of the Variscan basement (Arche and Lopez-Gomez 2005; LopezGomez et al. 2005; Figs. 2, 3). Most faults related with this extensional basin can be interpreted as reactivated Variscan, or older, NW-SE or N-S-trending structural lineaments, which were active from the Late Carboniferous-Early Permian periods (Vargas et al. 2009; Gutiérrez-Alonso et al. 2015). The Permian-Triassic record in the Iberian Basin includes felsic and mafic magmatic rocks (i.e., Early Permian granitoid and volcanic rocks in Perini et al. 2004), different sedimentary cycles and three regional angular unconformities.

Continental sediments and shallow-marine carbonates and evaporites (related with several transgressive pulses) were deposited at Early Permian to Middle Triassic (Anisian) in the eastern part of the basin and typically pass laterally into coastal and continental siliciclastic rocks along the axis of the basin. In particular, four sedimentary cycles, which are separated by unconformity contacts, can be recognised (Arche and Lopez-Gomez 2005; Lopez-Gomez et al. 2005): 
1. Early Permian in age and mostly made up of breccias and conglomerates (Tabarrena Fm. and Boniches Fm.) and associated andesitic to basaltic volcanic rocks locally overlain by variegated siltstones, dolomites and red breccias;

2. A Late Permian cycle consisting of alluvial-fan or braided-fluvial quartzite conglomerates (Boniches Fm.) of limited lateral extension and red siltstones, sandstones and conglomerates deposited by low- to high-sinuosity, avulsion-prone rivers with extensive floodplains (Alcotas Fm.); and

3. Represented by the Late Permian-Middle Triassic quartzite conglomerates of Hoz del Gallo Fm. with local top pink to red sandstones that lie unconformably above the Alcotas Fm. and, where missing, the Boniches Fm. During the Late Permian, intermediate to basic volcanic products erupted.

4. The continental Eslida Fm., consisting of lower Muschelkalk facies of the Late Anisian age, overlays (3).

Some Late Palaeozoic (Westphalian-Stephanian) basins are present in the Cantabrian zone of NW Iberia (e.g., the Ciñera-Matallana and Sabero Basins), which include calcalkaline volcanic and pyroclastic rocks (Knight et al. 2000). The Stephanian Ciñera-Matallana Basin is an E-W-oriented pull-apart basin (Frings et al. 2004; Fig. 2). The basin is a small intramontane sinistral pull-apart basin $\left(25 \mathrm{~km}^{2}\right)$ that developed during the late stages of the Variscan orogeny. It consists of Stephanian alluvial to lacustrine, coal-bearing sediments with a total thickness of $1500 \mathrm{~m}$. The basin developed in response to transpressional and then transtensional movements along the E-W-trending Sabero-Gordón sinistral strike-slip fault.

In the Balearic Islands, the NNW-SSE-oriented Permian-Triassic Minorca Basin (Gras and Zarza 2003, Fig. 3) comprises a 670-m-thick Permian succession of red mudstones, sandstones and gravels unconformably overlying the Upper Carboniferous Culm Facies. A classic Triassic Germanic-type sequence fills the grabens. From base to top, the sequence comprises non-marine clastic deposits (Buntsandstein facies), shallow-marine carbonates (Muschelkalk facies) and evaporites and clastic deposits (Keuper facies). The initial stages of rifting took place from the Late Permian to Triassic periods, during which Africa and Europe moved apart under a transtensional regime, leading to the formation of the network of graben systems.

In the southern Pyrenees, Lago et al. (2004) and Rodrìquez-Mendèz et al. (2016) identified within the Stephanian-Permian Basins (e.g., the Cadì and Anayet Basins) magmatism characterised by an E-W trend and two compositionally different igneous episodes, from Upper Carboniferous (Moscovian) to late Early Permian (Kungurian) calc-alkaline phase at 309-276 Ma (in Pereira et al. 2014), a following calc-alkaline/transitional-alkaline mid-Permian phase at 266-265 Ma (in Pereira et al. 2014) and a Mid- to Late Permian mildly alkaline phase. These two igneous episodes were related with the attenuation of Late Variscan transtensional tectonics and the onset of extension associated with regional rifting (Figs. 3, 4). The strike-slip fault systems that affected the Pyrenees area during the Late Variscan orogeny controlled the development and configuration of the sedimentary basins (Lago et al. 2004). In addition, these basins were periodically affected by extension, leading to their subsidence and the simultaneous emplacement of magmas. The wholerock trace-element patterns and isotopic signatures of the andesites suggest that they were derived from the upper mantle and were variably hybridised with late orogenic crustal melts, whereas the alkali basalts originated from a lithospheric mantle source that was enriched as a consequence of Variscan subduction.

\section{French Massif Central}

Among the Late Palaeozoic basins of the French Massif Central (e.g., Blanzy-Le Creusot, Autun and Rodez Basins), the Lodève Basin is one of the most complete and best-exposed Permian sections in Europe (Figs. 3, 4; Schneider et al. 2006). The basin is a half-graben structure with the E-W to NE-SW trending master strike-slip fault to the south (McCann et al. 2008) that can be interpreted as a conjugated branch of EVSZ (Fig. 3, Padovano et al. 2011). Permian sediments crop out over an area of 150 $\mathrm{km}^{2}$ with a thickness of $\sim 2500 \mathrm{~m}$. These sediments consist of grey continental fluvial-lacustrine sediments and red beds (Schneider et al. 2006). The first Permian sedimentary cycle begins with fluviatile conglomerates, sandstones and black lacustrine shales (the Asselian to Sakmarian Usclas-St. Privat and Tuilières-Loiras Fms.; Schneider et al. 2006). The second sedimentary cycle starts above a tectonically induced erosional unconformity with fanglomerate deposits passing upward into sheet-flood and braided-river sandstones and pelites (the Kungurian to Tatarian Rabejac Formation) (Pochat et al. 2005; Schneider et al. 2006). The retreat of the alluvial system and a transition into playa sediment deposition (Salagou Formation) is evident towards the top of this cycle. Tuff and tuffite beds occur within these two last formations and correlate with both the early calc-alkaline cycle and the subsequent alkaline cycle of Permian magmatism in Corsica. The sedimentary cycle is topped by the La Lieude Formation (Wuchiapingian to Changhsingian) (Schneider et al. 2006), which has coarse fluviatile clastic sediments at its base. 


\section{Sardinia, Corsica and Maures (Provence)}

The latest Carboniferous to Permian geological framework of the southern Variscides (e.g., Sardinia, Variscan Corse) developed within a regional continental transpressive and subsequently transtensile tectonic regime, with the deposition of continental sediments in pull-apart basins that were locally accompanied by plutonic and volcanic igneous events (Casini et al. 2012, 2015). The Permian-Carboniferous basins developed from south to north upon the low- to highgrade amphibolite-facies Variscan basement, locally intersecting the intrusive rocks of the Sardinia-Corsica batholith (Cortesogno et al. 1998a; Cassinis et al. 2003a, b; Buzzi and Gaggero 2008; Buzzi et al. 2008).

The record of sedimentation and its interplay with volcanism in the Sardinia-Corsica-Maures area have been investigated in many studies, including those of Rossi et al. (1991), Leroy and Cabanis (1993), Cassinis et al. (1997a, b, 1998,2003a, b), Cortesogno et al. (1998a), Deroin et al. (2001), Lapierre et al. (1999), Costamagna et al. (2000), Barca and Costamagna (2002, 2003, 2005, 2006), Costamagna and Barca (2002, 2008), Cassinis and Ronchi (2002), Aldinucci et al. (2006), Durand (2006), Bourquin et al. (2007), Durand (2008), Ronchi et al. (2008), Costamagna (2011a; b), Durand et al. (2011) and Gaggero et al. (2017) (Figs. 3, 4).

In Sardinia, Late Carboniferous-Permian or solely Permian basins are present both in the south-central region (the Seui, S. Giorgio, Perdasdefogu and Escalaplano-Mulargia Basins) and the north (the Nurra Basin) of the island. In the past, three main sedimentary cycles could be distinguished (i.e., the early molassic cycle in the Late Carboniferous-Early Permian, the molassic cycle in the Middle to Late Permian age and the post-molassic cycle in Early to Middle Triassic, Auct.). They are usually separated by marked unconformities, and even in the same tecto-sedimentary cycle there may exist important discontinuities, dividing different tectonic sub-phases (Deroin and Bonin 2003). Particularly in the Nurra area, the five sedimentary cycles are as follows (e.g., Cassinis et al. 2018):

(i) The first cycle is Gzhelian-Sakmarian in age and filled relatively small, half-grabens basins developed in a rugged and still well-articulated landscape related with the first extensional movements associated with local transpressive events. Its coal-bearing, fluvial-lacustrine filling (Punta Lu Caparoni Fm.) contains calc-alkaline volcanic intercalations that are also present at the top of the succession.

(ii) The second cycle consists of fluvial Sakmarian-Artinskian deposits (Pedru Siligu Fm.) with calc-alkaline volcanic rocks in the upper part (Casa Satta volcanic rocks). (iii) The third cycle is represented by the fluvial ArtinskianKungurian Portoferru Fm.

(iv) The fourth cycle includes fluvial deposits of Kungurian-Roadian age (Cala del Vino Fm.).

(v) The fifth cycle developed after a long mid-/late Permian to Early Triassic pp. tectonic stasis; it is represented by the well-known 'Verrucano Sardo' red beds of the Early to Middle Triassic times.

These deposits mark the renewal of extensional tectonic activity and are associated with different basins in Sardinia (Costamagna and Barca 2002), narrower in size and thinner in sedimentary filling, which are represented by prevalently continental Buntsandstein-type red bed siliciclastic successions (e.g., Porticciolo conglomerate Fm. and Cala Viola Fm. in Nurra), capped by Middle Triassic Muschelkalk to Keuper German-type facies.

The first and second cycles belong to the main regional Late Carboniferous-Early Permian cycle, whereas the third and the fourth can be correlated with the mid-Permian cycle as defined in typical areas of southern Europe (e.g., Southern Alps and Northern Apennines).

The widespread syn- to post-collisional plutonism in Sardina-Corsica covers a 340 to 288 My time interval (Poli et al. 1989; Cocherie et al. 2005). Monzogranite and leucogranite with minor gabbro-diorite to tonalite in Sardinia show ages between 307 and $281 \mathrm{Ma}$ and a typical calcalkaline chemical character (Poli et al. 1989). Cocherie et al. (2005) defined three main groups of granitoid rocks in Corsica:

(1) The earliest, U1, is made up of c. 340 Ma syn-collisional granitoid rocks.

(2) The second, U2, is composed of calc-alkaline early granodiorite and monzogranite (c. $300 \mathrm{Ma}$ ) and late leucomonzogranite (c.290 Ma).

(3) The third, U3, is composed of anorogenic metaluminous and alkaline granites 291-287 Ma, associated with $c .286$ Ma tholeiitic layered complexes and dykes.

The conspicuous volcanic record in Sardinia encompasses a wide range of intermediate-silicic magmas, including medium- to high-K calc-alkaline andesites, dacites and rhyolites. Interplay among syn- to late-orogenic volcanism, sedimentation and tectonic activity took place during the latest Carboniferous and Permian, post-dating the unroofing and erosion of the Variscan nappes.

Gaggero et al. (2017) identified within the igneous volcanic rocks three main groups of concordant $\mathrm{U}-\mathrm{Pb}$ ages, using Laser Ablation-Inductively Coupled Plasma-Mass Spectrometry (LA-ICP-MS) analyses of zircon, that correspond closely with the biostratigraphic data of the Carboniferous-Permian successions: 
(i) an oldest group of $332 \pm 12 \mathrm{Ma}$ (Mt. Cobingius andesite cutting the medium-grade metamorphic basement constraining the onset of igneous activity on unroofed middle crust) and a $302 \pm 2.9$ Ma rhyolite (Escalaplano rhyolite),

(ii) a second group with ages between $297 \pm 2$ (Lu Caparoni Ignimbrite) and $294 \pm 3$ (Perdasdefogu dacite) within the time interval of the first sedimentary cycle. It is notable that the youngest age $(295 \pm 3$ Ma) was obtained from the southeastern basin and the oldest age $(297 \pm 2 \mathrm{Ma})$ from the northwestern one.

(iii) a youngest age of $288 \pm 2 \mathrm{Ma}$ (Case Satta ignimbrite, Nurra Basin). Ages (ii) and (iii) can be linked with the progressive development of continental strikeslip faulting from the south (the Escalaplano Basin) to the north (the Nurra Basin).

Finally, N-S-trending dolerite dikes are emplaced from north to southeast Sardinia across the Early Palaeozoic medium- to high-grade metamorphic basement, the Sardinia-Corsica batholith and Stephanian-Autunian calcalkaline effusive deposits. The tholeiitic to transitional dolerites have an anorogenic affinity and are associated with $\mathrm{E}-\mathrm{W}$ - to N-S-trending diorite to rhyolite dikes. The dolerite emplaced between $253.8 \pm 4.9$ and $248 \pm 8 \mathrm{Ma}$ (Late Permian-Early Triassic; ${ }^{40} \mathrm{Ar}-{ }^{39} \mathrm{Ar}$ ages on amphibole; Gaggero et al. 2007). The $\mathrm{Nd}$ isotopic ratios point to a source in a subcontinental lithospheric mantle. The E-W emplacement trend of the dolerite dike swarm matches the E-W orientation of Late Variscan transcurrent-extensional faults, whereas the subsequent $\mathrm{N}-\mathrm{S}$ emplacement trend of the dolerite dike swarm is consistent with a general E-W-directed extension of the Sardinian crust and more generally with the direction of extension between the European and Insubric crusts at the beginning of Tethyan rifting (Gaggero et al. 2007). Alkaline pyroclastic rocks and lava flows are present within the Early Triassic Buntsandstein facies in Nurra (Cassinis et al. 1996). Finally, one Late Triassic lamprophyric dike, NE-SW oriented, cuts the E-W-trending Posada Valley shear zone ( $240 \pm 11$ to $224 \pm 11 \mathrm{Ma}$, apatite fission-track dating; Baldelli et al. 1987). On the whole, the anorogenic geochemical affinity of the dikes is in agreement with an extensional regional tectonic regime in the Middle to Late Triassic times.

\section{Ligurian and Western Alps}

The Late Carboniferous-Early Permian volcano-sedimentary successions of the Ligurian Alps were deposited unconformably on the pre-Variscan basement (Cabella et al. 1988; Cortesogno et al. 1988, 1992, 1993, 1995, 1998a, b; Gaggero et al. 2004; Decarlis et al. 2013; Cassinis et al. 2018) and were truncated by a Late Permian unconformity. Although the Carboniferous intrusive record is patchy in the Ligurian Alps, sparse alkaline granitoid bodies are preserved in Alpine nappes (Cortesogno et al. 1996).

The basement of the Alpine Mallare Unit (Barbassiria orthogneisses) has been dated at 320-315 Ma (i.e., early Late Carboniferous). This basement was then overprinted by a high-temperature (greenschist-amphibolite facies) Variscan metamorphic event that was likely associated with tectonic burial and compression during the final stages of the Variscan collision (Maino et al. 2012, 2019).

The Bashkirian-Moscovian basal conglomerate in the Ligurian Alps (Ollano and Lisio Fms.) is heteropic and contains calc-alkaline rhyolitic ignimbrites and tuffs (C. Lisetto Formation, 285.6 $\pm 2.6 \mathrm{Ma}$; Dallagiovanna et al. 2009). In addition, the Palaeozoic basement is locally cut by andesitic dikes (Buzzi and Gaggero 2008). The overlying conglomeratic-sandy-pelitic, fluvial-lacustrine deposits (Murialdo and Ollano Fms.) are interbedded with ignimbritic and pyroclastic agglomerates (the Osiglia Porphyries, dated at $278 \pm 3.4 \mathrm{Ma}$ ). The continental suite evolves towards finegrained sediments (Gorra Fm. and Viola schists), interbedded with andesitic lavas and pyroclastites up to $250 \mathrm{~m}$ thick (Eze Fm.). Above a c. 14 My unconformity, a huge volume of calc-alkaline rhyolitic to dacitic ignimbrites of the Melogno Porphyroids, dated at $272.7 \pm 2.2$ Ma was emplaced (Kungurian, Dallagiovanna et al. 2009).

The Late Palaeozoic igneous activity ends with polychrome K-rhyolitic fine to medium-grained ignimbrites dated at $258.5 \pm 2.8 \mathrm{Ma}$ (Wuckiapingian, Dallagiovanna et al. 2009). The K-rhyolites were coeval with the emplacement of rhyolite dikes cutting the Variscan basement $(260.2 \pm 3.1)$. and truncated by overlying Upper Permian unconformity with the Lopingian fluvial deposits (Briançonnais Verrucano conglomerates) passing upward into the well-sorted fluvial Scythian Ponte di Nava Quartzites Fm. (Cassinis et al. 1998; Costamagna 2018); in the Verrucano, phosphate mineralisations represent a chemical proxy for processes related with continental dismantling and arid climates (Cortesogno et al. 1987).

The Scythian-Anisian transition is represented by the ankeritic green shales of the Case Valmarenca Pelite, while, in the Prepiedmont units, thin-bedded, fine micaceous calcarenites and calcsiltites are present. Then follows the marine middle-upper Triassic succession.

In the Ligurian Alps basement, temperatures exceeding $\sim 240 \pm 25^{\circ} \mathrm{C}$ before $\sim 160-150 \mathrm{Ma}$ (Late Jurassic) have been measured by zircon fission-track analyses on basement rock samples at a few kilometres depth (Decarlis et al. 2017). Such a heating-cooling cycle developed during the development of rifting at the Alpine Tethys margin and ended during the Late Jurassic (160-150 Ma). The subsequent onset of seafloor spreading was characterised by crustal 
and lithospheric thinning and high geothermal gradients $\left(60-90^{\circ} \mathrm{C} / \mathrm{km}\right)$.

The Ligurian segment of the Southern Variscan belt is interpreted as recording transtension followed by extensional tectonics, as indicated by the evolution of associated volcanic activity (Fig. 3). The switch from a calc-alkaline to an alkaline chemical magmatic fingerprint corresponds to the transition from a post-orogenic to an anorogenic setting. This has been interpreted as a progressively increasing delamination of the continental lithosphere, accompanied by the partial melting of lithospheric mantle (Dallagiovanna et al. 2009).

Several Late Palaeozoic basins are present in the Western Alps (Ballèvre et al. 2018). There, the NW-SE-oriented St. Étienne and the E-W-oriented Tende Late Carboniferous basins (Figs. 3, 4) were developed in the Argentera area and related with a NW-SE-trending strike-slip shear zone (Corsini et al. 2004), active during the Late Carboniferous (the Valetta and Bersezio shear zones).

To the north, the N-MORB/T-MORB Versoyen tholeiites, dated at $337 \mathrm{Ma}$ (Mugnier et al. 2008) suggest the presence of a small ocean (Beltrando et al. 2007) close to the continental margin where the coal-bearing Carboniferous basins of the Briançonnais Zone developed (La Thuile Basin in the Houilliére Zone; Ballèvre et al. 2018). The evolution of the NE-SW-oriented, Carboniferous La Thuile Basin (Valente and Borghi 2000) is consistent with lithospheric stretching, which peaked during the Visean, locally producing the Versoyen tholeiites (Timmerman 2004). The La Thuile Basin includes two sedimentary series (Valente and Borghi 2000): (1) the lower series (Namurian-lower Stephanian), which consists of anthracite-bearing sandstone and pelite with local sub-volcanic calc-alkaline intrusions and (2) the upper series, represented by variably coloured Middle-Upper Stephanian conglomerates and pelites with locally abundant volcanoclastic intercalations, unconformably overlain by Permian-Triassic 'Verrucano'-like, mostly ruditic redbeds.

In the Mt. Blanc area, the Late Westphalian-Early Permian, NE-SW-oriented Salvan-Dorénaz Basin of the Helvetic Zone is interpreted as syn-kinematic with a NE-SWtrending dextral-shear zone (Capuzzo and Bussy 2001; Figs. 3, 4). The authors distinguished four different fluvial units characterised by alluvial fan, anastomosed and meandering fluvial facies. Calc-alkaline volcanism was active throughout the evolution of the basin, as suggested by the $308-295 \mathrm{Ma} \mathrm{U} / \mathrm{Pb}$ radiometric age of the magmatic products.

The same tectonic regime was inferred since the Upper Carboniferous in the nearby Emosson Lake by Genier et al. (2008) and Ballèvre et al. (2018). In agreement with Padovano et al. (2011, 2014), Ballèvre et al. (2018) associated the formation of these basins with the trans-tension process along the EVSZ and pointed out its reactivation in Permian times as well.

\section{Central Alps}

In the central Tauern Window (Austria), three plutonicvolcanic stages were recognised by Eichhorn et al. (2000):

(i) 340-343 Ma syn-collisional anatectic high-K, I-type plutonism and extrusive rhyolitic/dacitic products;

(ii) 296-279 Ma calc-alkaline, I-type granitoid rocks and minor coeval bodies of felsic and intermediate volcanic rocks connected to the Late Carboniferous trans-tensional/-compressional activity;

(iii) 271-279 Ma S-type granitoid rocks and rhyolites probably associated with extension phenomena along the persistent wrench zones.

Therefore, the magmatic events are coeval with the activity of a NE-SW-trending strike-slip shear zone, therefore constraining the evolution of the NE-SW-striking Stephanian-Early Permian, volcano-sedimentary basins (Eichhorn et al. 2000; Figs. 3, 4).

\section{Northern Apennines}

The Late Carboniferous-Permian successions in the Northern Apennines (Tuscany) are low-grade metamorphic sequences belonging to the deepest Tuscan metamorphic unit (Pandeli 2002, and references therein). The tectonosedimentary evolution of these successions has been interpreted in terms of deposits in pull-apart basins linked to the extensional activity of megashears that developed during the Late Variscan orogeny and the early stages of Alpine rifting (Rau and Tongiorgi 1980; Rau 1990, 1993; Pandeli 2002). Currently, three main Late Palaeozoic post-Westphalian sedimentary cycles (separated by unconformity surfaces) can be defined as follows:

1. The Kasimovian/Gzhelian to Sakmarian (late Carboniferous-early Permian) cycle, which is coeval with Late Carboniferous half-graben sedimentation in Sardinia, consists of fossiliferous fluvial to neritic, organic-matter-rich sediments (S. Lorenzo Fm.: Rau and Tongiorgi 1974; Iano schists and sandstones: Landi Degl'Innocenti et al. 2008; Spirifer Schists: Costantini et al. 1998; and Rio Marina Fm.: Bortolotti et al. 2001) that were deposited in an extensional/transtensional regime at the end of Variscan shortening (Sudetian and Asturian events) under a humid equatorial climate.

2. The Sakmarian/Artinskian to Roadian (latest early Permian to mid-Permian) cycle is represented by reddish, mostly coarse-grained and immature sediments (Asciano 
and Torri breccia and conglomerates; Rau and Tongiorgi 1974; Costantini et al. 1998; Pandeli 1998) that show interbedding and a lateral-vertical contact with acidic metavolcanic rocks (Iano Porphyritic Schists; Costantini et al. 1998; Pandeli 1998, 2002). The succession is interpreted as alluvial-fan or fluvial deposits laid down under an inter-tropical, semi-arid climate and originating during the block faulting of the Saalian rejuvenation extensional event. This succession can be correlated with Southalpine analogues, the Ponte Gardena Conglomerate and the Athesian Porphyry Plateau (see later discussion).

3. The Capitanian to Changhsian (latest mid-Permian to late Permian) cycle consists mainly of reddish fluvial, volcanic-rich sediments (Borro del Fregione siltstone and sandstone, Castelnuovo Red Sandstone; Pandeli 1998, 2002) in western Tuscany. These sediments are associated with the Palatine extensional event during which erosion of the volcanic relief occurred, similar to the Val Gardena sandstone-Verrucano Lombardo in the Southalpine area (see later), and grade upward into a Permian-Triassic marine transgressive succession. In eastern Tuscany, Upper Permian commonly turbiditic marine siliciclastic and fossiliferous carbonate sequences are exposed (e.g., Farma Fm., Carpineta Fm. and Poggio al Carpino Sandstone; Aldinucci et al. 2006) and are consistent with the subsurface geology (Elter and Pandeli 1990, 1991; Pandeli and Pasini 1990; Corsi et al. 2001).

The three cycles are unconformably overlain by ?Late Ladinian-Carnian, syn-rift, quartz-rich fluvial sediments (Verrucano Auct.) at the base of the main Alpine sedimentary cycle, but a ?Scythian-Ladinian continental-to-marine cycle with interbedded intraplate pillow lavas has been recognised locally in Tuscany (e.g., the first cycle of Verrucano at Punta Bianca, in Martini et al. 1986; Abbate et al. 2005). The Saxonian-Thuringian and (?) Scythian-Ladinian cycles are considered as 'aborted rift basins' from the repeated attempts of crustal breaking in the Tuscan sector of Gondwana. These phenomena are well explained in a transpressive/-tensional regime along long-living megashear structures (Rau 1990, 1993; Pandeli 2002).

\section{Southern Alps}

The Southern Alps contain several NE-SW-oriented domino-like pull-apart Permian basins, all of which developed concurrently with strike-slip shear events (Varesotto-Luganese area, Orobic Basin, Collio Basin, Val Rendena area, Tregiovo-Mt. Luco Basin, Bolzano-Trento Basin and Western Dolomites) (Cassinis and Perotti 1994; Cassinis et al. 1997a, b, 1998, 2008, 2012; Cortesogno et al. 1998a, 1998c;
Bernoulli et al. 2018). Handy and Zingg (1991), Deroin and Bonin (2003) and Schaltegger and Brack (2007) proposed that the Mid-Permian unconformity originated during largescale strike-slip tectonics and erosion, associated with crustal thinning, upwelling and the partial melting of mantle, as well as the advection of melts and heat into the crust (Figs. 3, 4).

In the Southern Alps domain (from Lombardy to the Carnic Alps), two main Carboniferous to Late Permian sedimentary cycles (Cassinis et al. 2007, 2018 and references therein) are separated by a Mid-Permian regional unconformity (Cortesogno and Gaggero 2011). As in the Carboniferous to Triassic sedimentary evolution of the Northern Apennines, three sedimentary cycles are recorded, as follows:

1. The Late Carboniferous-Early Permian cycle in the Carnic Alps and pre-Alps is represented by a succession containing immature basal conglomerates and breccias (Bombaso Fm.) passing upward and laterally to shallowmarine clastic and carbonate rocks (Auernig group) and in turn to the Upper Permian Pontebba Supergroup, including mainly carbonate rocks (e.g., Trogkofel limestone).

2. The "mid-Permian" (mid-/upper Cisuralian) cycle is represented particularly in the Central Alps (e.g., the Brescia area) and in the Dolomites as successions which directly overlie the Palaeozoic crystalline basement. The base consists mainly of conglomerates, which are overlain by fluvial-lacustrine clastic sediments (Collio Fm., Dosso dei Galli conglomerate, Ponte Gardena conglomerate; Cassinis 1988). Calc-alkaline magmatism, represented by rhyolites/rhyodacites, basaltic andesites and andesites, followed, producing volcanoes and thick volcanic platforms in the 285-274 time interval (e.g., the Athesian volcanic platform, Di Battistini et al. 1989; Bargossi et al. 1993; Marocchi et al. 2008) or locally as intrusive domes (Schaltegger and Brack 2007; Cassinis et al. 2007; 2018), which are coeval with basic intrusions in the middle-lower crust. The sub-intrusive bodies were locally also reworked in post-eruption mass flows (Breitkreuz et al. 2002).

3. The mid- to Late Permian cycle is represented in the entire Southalpine area as widespread syn-rift deposits at the base of the Alpine sedimentary cycle (Cassinis et al. 2018). These commonly coarse-grained, reddish continental fluvial sediments together form the Verrucano Lombardo o Val Gardena Sandstone (Groden Fm.) and were derived from the erosion of Mid-Permian volcanic rocks and of the Palaeozoic crystalline basement. In Lombardy, these deposits pass upward to finer clastic sediments, whereas in the Dolomitic area they grade upward into evaporitic deposits (Bellerophon Fm.) 
that occur at the base of the Triassic marine succession (Werfen Fm.) (McCann et al. 2008).

\section{Late Palaeozoic basins in the surrounding of EVSZ}

\section{Morocco-Algeria}

The Stephanian and Permian sediments in central Morocco (Meseta Area, High Atlas Mountains; Voigt et al. 2011) document the evolution of this region during the formation of the Mauretanide portion of the Variscan chain and testify to the formation of Late Palaeozoic continental basins characterised by a NE-SW strike (Hmich et al. 2006) (Figs. 3, 4). These basins (e.g., the Khenifra and Souss Basins in Central Morocco) are characterised by a Late Stephanian-Lower Permian lithostratigraphy comprising three members (Hmich et al. 2006; Voigt et al. 2011). The lower member consists of stacked, mainly coarse-grained deposits of an alluvial-fan to alluvial-plain environment. The intermediate member contains predominantly red and grey mudstones, representing deposition on an extended floodplain, and contains lower Permian tetrapod footprints. The upper member, characterised by a basal erosional unconformity and consisting of fluvial conglomerates and fine-grained sandstones, is likely related with largerscale syn-rift tectonics and/or climatic events (Olsen et al. 2000). Subsequently, late Early Permian rhyolitic-rhyodacitic volcanism and the following dacitic-andesitic igneous activity formed a widespread calc-alkaline Permian volcanic cover (Aït Chayeb et al. 1998). The overlying Late Permian cycle is made up of fluvial conglomerate and sandstones and includes the first product of alkaline/ intermediate magmatism, i.e., basic necks and dykes (Ait Chayeb et al. 1998). The occurrence of overlying Late Triassic-Early Jurassic basalts, dated at 201-196 Ma (Verati et al. 2007), is interpreted as the beginning of the main rifting associated with the breakup of Pangaea (Saddiqi et al. 2009).

In Algeria, the filling of the sedimentary basins in the Algerian Saharan craton, south of the Saharan Atlas orogenic front (e.g., the Oued Mya, Murzuq, Illizi and Ahnet Basins; Figs. 1, 2) includes Early to Late Carboniferous, and, rarely, Early Permian successions, which are unconformably overlain by Triassic sediments and conspicuous Late Triassic volcanic rocks (Popescu 1995; Boote et al. 1998; Derder et al. 2009, 2014; Wang et al. 2009; Henry et al. 2014). Moreover Derder et al. (2009) underlined the presence of a syn-sedimentary compressive event during the Early Permian.

\section{Germany}

In central Germany, the Carboniferous-Permian Saar-Nahe Basin (Schafer 2011; Fig. 3) is formed as an asymmetric half-graben overlying the pre-Variscan basement rocks of the Saxothuringian Zone (metamorphic schists of the Northern Phyllite Zone) and granitoid rocks of the Mid-German Crystalline Rise. Schafer (2011) proposed that the Late Carboniferous South Hunsrück dextral strike-slip fault was the transtensional structure that allowed the formation of the basin.

The Elbe Shear Zone (ESZ in Figs. 1, 2, 3) is a NW-SEtrending dextral intracontinental strike-slip shear zone and was active between 320 and $300 \mathrm{Ma}$. The strain ellipsoid related with the kinematics of the $\mathrm{N}-\mathrm{S}$-trending Permian Lower Saxony Rift System (McCann et al. 2008) accounts for the final stage of the NW-SE-directed ESZ shearing.

\section{Dinarides, Hellenides, Balkans and Moesia}

In Slovenia, Schwarb and Spangenberg (2004) described the NW-SE-oriented Late Palaeozoic basin of the Idrjica Valley characterised by Mid-Late Permian clastic red beds that pass vertically to Late Permian-Early Triassic shallow marine carbonates (Figs. 3, 4). The External Dinarides successions comprise Carboniferous-Early Permian epeiric platform limestones that underlie syn-rift, late Early Permian, polymictic conglomerates grading upward into shallow marine carbonates (Aljinovic et al. 2008). In the Hellenides, the Peloponnesus succession is dominated by Late Carboniferous-Permian shallow, sub-tidal, mostly clastic sediments (Plattenkalk and Tyros Groups in Dornsiepen et al. 2001; Hymerrkus et al. 2007) that underlie Late Permian-Triassic neritic deposits through a late lower Permian unconformity. To the south, the E-W-striking Crete Basin has a complex Late Carboniferous-Permian pelagic filling: the western part is dominated by turbiditic siliciclastic deposits, whereas the middle and eastern parts are characterised by alternating carbonates and pelites (Phyllite-Quartzite Group in Dornsiepen et al. 2001); the latter change southwards to shallow water deposits on a carbonate platform (Plattenkalk Group of Crete in Dornsiepen et al. 2001). Most of these Late Palaeozoic basins developed along the ESZ-Tisia-Moesia megashear alignment during at least the Late Carboniferous times (Padovano et al. 2014), but also continued their activity locally during Permian-Triassic times (Dornsiepen et al. 2001).

This structure was also active during the collapse of the Balkan orogen and formed a series of diachronic, mostly E-W or WNW-ESE-striking, Late Carboniferous-Early Permian basins with calc-alkaline volcanic rocks and subvolcanic bodies (e.g., Svoge, Sofia-Stara Planina, Godech and Buchino-Petrohan Pass Basins in Cortesogno et al. 
2004a). The Upper Permian continental red beds and overlying Triassic Buntsandstein sediments followed after a MidLate Permian stratigraphic gap. No evidence of magmatism was recognised in the Late Permian, but the extension before the Moesia breakup is recorded by Triassic alkali basalt and trachytic lavas that were erupted in continental successions grading to marine (Cortesogno et al. 2004b).

\section{Discussion}

A distinctive feature of the Carboniferous (locally since Namurian)-Permian to Triassic basins is their genetic relationships with coeval tectonics related with intracontinental shear zones, as established by several Authors (e.g., Bonin et al. 1987; Rau 1993; Cortesogno et al. 1998a; Ziegler and Stampfli 2001; Gutiérrez-Alonso et al. 2004, 2008; Padovano et al. 2011, 2014; Edel et al. 2015; Ballèvre et al. 2018). In particular, most of these basins are aligned along a zone of continental fragmentation running from the Alps to North Africa characterised by a NE-SW-trending dextral strike-slip movement (i.e., the EVSZ; Padovano et al. 2011, 2014) that was subsequently cut by other major WNW-ESEtrending shear zones (e.g., ESZ and SGBFZ in Fig. 1).

The location and tectono-sedimentary features of these basins and their relationship with subsequent igneous activities are fundamental elements in the reconstruction of the Carboniferous-Permian geodynamics. In particular, the widespread calc-alkaline magmatism was attributed in the past to an arc associated with Devonian subduction of the Paleotethys (Nicholls and Lorenz 1973; Buchs 2013), but this hypothesis conflicts with the regional igneous evolution (acid-intermediate-acid products) as well as with their geodynamic context. To account for the stratigraphic and tectonic constraints, the early interaction between subcrustal and crustal anatectic magmas, followed by assimilation and fractional crystallisation, has been proposed (Cortesogno et al. 1998a; Buzzi et al. 2007, 2008). Another important aspect is that the calc-alkaline magmatism changed into alkaline-type in the Upper Permian, although at the MidPermian the overlap of the two suites was locally evidenced and related with an important variation in the geodynamic framework (e.g., Deroin and Bonin 2003; Cortesogno et al. 2004a; Cocherie et al. 2005).

\section{Evolution of pull-apart basins}

In North Africa, the Carboniferous-Permian basins are located at the boundary of the Saharan shield to the south of the Atlas Orogenic belt. In Morocco-Algeria, the Meseta and Oued Mya Basins are linked to the dextral W-E-trending shearing along Atlas Shear System (ASheS) in the main. Instead, we interpreted the Late Palaeozoic basins in Tunisia (e.g., the Tebaga of Medenine Basin) as the southernmost one produced by the EVSZ that can be possibly continued eastwards into the ASheS (Fig. 1).

In southern Europe (i.e., the area of peri-Gondwanaderived microcontinents, GDC in Fig. 1), all the Late Carboniferous-Permian basins were related with the presence of a shear zone network. In particular, the Iberian Basins (the Iberian Ciñera-Matallana, Minorca and southern Pyrenees Basins) and the French basins (Lodève, Blanzy-Le Creusot, Autun, and Rodez Basins) are all regarded as pull-apart basins that formed concurrently with the shearing network (Van Wees et al. 1998; Gras and Zarza 2003; Frings et al. 2004; Lago et al. 2004; Arche and Lopez-Gomez 2005; Lopez-Gomez et al. 2005; Schneider et al. 2006; McCann et al. 2008). Their tectonic evolution ceased with the onset of Triassic rifting, as in the Morocco-Algeria-Tunisia region.

Many Late Palaeozoic basins can be recognised along the intracontinental EVSZ: the Western, Central and Eastern Alps, Sardinia, Corsica, Maures and Northern Apennines Basins are all considered to be half-graben/pull-apart basins (e.g., Rau 1993; Eichhorn et al. 2000; Valente and Borghi 2000; Capuzzo and Bussy 2001; Pandeli 2002; Cassinis et al. 2003b, 2008, 2012; Corsini et al. 2004; McCann et al. 2008; Mugnier et al. 2008; Ballèvre et al. 2018; Costamagna 2019). Notably, the Late Carboniferous, N-MORB/TMORB tholeiites were emplaced during the opening of the Versoyen Basin of the Western Alps (Mugnier et al. 2008), which is consistent with EVSZ activity. In particular, it has been interpreted as an incipient oceanisation zone contiguous with the coeval Carboniferous continental La Thuile Basin (Valente and Borghi 2000) developed on the Briançonnais margin. In the Helvetic area, a NE-SW-trending dextral-shear zone was active between the Carboniferous and the Permian, producing the syn-kinematic Emosson Lake and Salvan-Dorénaz Basins in the Mt. Blanc sector (Capuzzo and Bussy 2001; Genier et al. 2008). In the Tauern Window (Central and Eastern Alps), within an evolving NE-SW-oriented Carboniferous-Permian basin related with a NE-SW-trending strike-slip shear zone, granitoid bodies were emplaced between 279 and $271 \mathrm{Ma}$ (Eichhorn et al. 2000) similar to that defined in the basement of the Aar, Aiguilles-Rouges and Mt. Blanc massifs of the Helvetic zone in Western Alps.

In central and eastern Europe (i.e., the Saxonian-Dinarides-Hellenides tectonic realm), the Late Carboniferous-Early Triassic basins substantially record the same tectono-sedimentary evolution as that of the North Africa and Southern Europe basins. The EVSZ is probably cut by the NW-SE-trending ESZ at its eastern end (Fig. 1; Dornsiepen et al. 2001). The ESZ is a mainly dextral intracontinental strike-slip shear zone that was active between 320 and $300 \mathrm{Ma}$, so partially coeval with EVSZ. Taking into account the strain ellipsoid related with the kinematics of the ESZ 
shear zone, the N-S trend of the Permian Lower Saxony Rift System (McCann et al. 2008) is in agreement with the final stage of the shearing along this structure.

In addition, the Saar-Nahe Basin in western Germany (Saxothuringian Zone) was interpreted by Schafer (2011) as a pull-apart basin related with the NE-SW-trending dextral South Hunsrück Fault, which was active from the Late Carboniferous to the Permian, similarly to the ESZ.

The ESZ probably continued southwards along the NW-SE-trending Tisia-Moesia lineament up to the island of Crete, through the scattered Permian-Triassic rhomb-graben structures in the Dinarides (the Idrjica Valley in Slovenia), in the Hellenides (e.g., the Peloponnese; Dornsiepen et al. 2001; Schwab and Spangenberg 2004; Aljinovic et al. 2008; Bortolotti et al. 2013) and in the Balkan area (Cortesogno et al. 2004a). It is also noteworthy that the Carboniferous-Permian sedimentation changed from shallow marine to deep marine, locally characterised by siliciclastic turbiditic successions (e.g., western Crete). The presence of a pelagic basin in this area suggests its probable genetic link with the PaleoTethys (Fig. 1).

The previous chapter showed that these structures are genetically linked to the syn- to late-orogenic Variscan shearing events that occurred during the Carboniferous-Early Permian (e.g., Arthaud and Matte 1977; Ballèvre et al. 2018), but at least some of their activity continued locally during at least the Mid- and Late-Permian times and later (e.g., the reactivation of EVSZ several times, in Ballèvre et al. 2018) and is coeval with the Cimmerian rifting that allowed the opening of the NeoTethys to the east (Cassinis et al. 2018; Stampfli and Borel 2002; Stampfli and Kozur 2006).

\section{Tectono-sedimentary cycles and magmatism}

The sedimentary evolution of the various asymmetric intracontinental basins in the studied areas is synthesised in Fig. 4. The basins can be broadly divided into sedimentor volcanic-dominated basins. In particular, the sedimentdominated successions exhibit unconformities believed to have originated from changes in tectonic style (compressive vs. extensional). Instead, the regular emplacement of Late Permian calc-alkaline rocks followed by transitional and then alkaline volcanic rocks, is a widespread feature of the volcanic-dominated basins. In these basins, changes in tectonic kinematics and subsidence within structures are indicated by sedimentary features (fluvial-lacustrine to marine) and by the relative proportions of intrusive versus effusive igneous products. At least three main unconformities can be identified in the Carboniferous-Permian record in most of the considered basins, thus defining them as the result of several different sedimentary cycles. Most of these cycles are related with concurrent transtensile activity upon the major shear zones, producing sedimentary basins whose filling was interrupted by transpressive events that produced the basal unconformities for the following cycles. Taking into account the data from the different areas, the following main unconformities can be pointed out.

Upper Carboniferous (Lower Pennsylvanian, i.e. Moscovian) unconformity. This unconformity is generally related with the Asturian orogenic phase of the Variscan Orogeny that marks the main dextral megashear activity within the orogen itself. In the associated pull-apart basins, the typical clastic and organic-matter-rich Stephanian-Autunian successions were generally deposited in a humid, reducing fluvial-lacustrine to neritic environment. At any rate, the oldest basins are also present locally, as in the NamurianStephanian La Thuile Basin in the Western Alps. Acidic to intermediate volcanic rocks (rhyolites, rhyodacites and quartz latites) are locally intercalated in the sedimentary successions (e.g., the Ligurian and Southern Alps). Calcalkaline and anatectic granodiorite and tonalitic plutons, as well as composite batholiths, are also present, particularly in Sardinia and Corsica.

Early Permian (mid-upper Cisuralian, i.e. Sakmarian/ Artinskian) unconformity. This unconformity is related with a rejuvenation of the Variscan landscape (the Saalian event), due to the local reactivation of the compressional tectonics. As a result, this sedimentary cycle is not as widespread along the studied shear zones as are the other cycles. The filling of these basins is represented generally by alluvial-fan to fluvial, coarse- to medium-grained, commonly immature, red beds that were deposited in a semi-arid continental environment. Calc-alkaline volcanic bodies (generally rhyolitic to rhyodacitic ignimbrites, pyroclastic flows and tuffs) are common and locally thick (e.g., the Athesian Volcanic Platform). Elsewhere, the intrusion of leucogranite bodies and porphyritic granitic dikes is recorded (e.g., Sardinia).

Mid-Permian (Kungurian-Roadian) unconformity. This unconformity is associated with the so-called Palatine event, during which the volcanic edifices and their host basements were eroded. These younger basins contain typical alluvial-fan or fluvial to coastal-plain red beds (conglomerates grading to sandstones) characterised by volcanic-rich compositions (e.g., Val Gardena Sandstone and Verrucano Lombardo in the Southern Alps and Castelnuovo red sandstones in the Northern Apennines). Locally (e.g., the Southern Alps) these deposits represent the base of the Alpine sedimentary cycle passing conformably upward to transgressive, Permian-Mesozoic marine sediments. No Late Permian continental successions are present in the eastern parts of the Northern Apennines where coeval Late Permian clastic (e.g., the turbiditic Farma Fm.) and carbonate, neritic to probably deep-marine sediments were found. Alkaline magmatism 
(including alkaline granites and syenites) is typical and locally well developed (e.g., in the Sardinia, Corsica and Provence regions).

The early Permian event represents a main "watershed" in sedimentary evolution because at least part of the organic-matter-rich Carboniferous-Early Permian successions pass sharply upward to generally immature, coarse-grained red beds that are related not only to an important tectonic pulse but also to a climatic variation. In fact, during Mid- to Late Permian times the considered areas passed from a wet equatorial climate to arid, oxidising conditions of the boreal intertropical belt (Rau and Tongiorgi 1974; Scotese 2001; Stampfli and Borel 2002; Schneider et al. 2006; Stampfli and Kozur 2006; Scotese and Wright 2018). This event can be related in part to the movement along the mega shear zones, but also to the reorganisation of the terrains in a new paleogeographic configuration (e.g., the transformation of Pangaea A in Pangaea B). Another important change occurred in late early/mid-Permian times because in some sectors the 'anorogenic' alkaline magmatism (which was typical in Late Permian-Triassic) overlapped the dominant 'orogenic' calc-alkaline one (Bonin 1988, 1998; Cocherie et al. 2005). According to different authors, this also marks a variation of the tectonic regime, i.e., post-Variscan orogenic extension and beginning of the Alpine rifting (e.g., Cassinis et al. 2018), or the inversion of the movements from dextral to sinistral within the main shear bands (e.g., Deroin and Bonin 2003).

We have no new data to support one of the above hypotheses, but the local appearance of Late Permian marine successions at the base of the Alpine transgressive sedimentary cycle in eastern areas suggests the beginning of an important regional extensional/trans-tensional stage probably connected with the opening of NeoTethys ocean. This led first, to the development of seaways and then to the Western Tethys, such as the Jurassic Ligurian-Piedmont Ocean, through a main sinistral transcurrent regime (Bortolotti et al. 1990, 2001). In other places, this transgressive sedimentary trend was interrupted during the Late Permian-Middle Triassic time interval, as shown in the Northern Apennines (the 'aborted rift' cycles in the Late Permian and Early-Middle Triassic, in Martini et al. 1986; Pandeli 2002). The main Alpine cycle began with the Late Ladinian Verrucano red beds (the Middle Triassic unconformity). These aborted events point to the idea that that some sectors of the considered belt were subjected to frequent variation in the shearing regime (transtension to transpression) along a single shear zone or were characterised by the influence of shear zones with different regional strikes until the final breakup of the Variscan crust.

\section{Conclusion}

The geographic distribution and structures of the Carboniferous-Permian to Triassic basins, together with their sedimentary and igneous features, allow us to determine that the Late Palaeozoic network of intracontinental shear zones formed an axis of tectonic weakness along which these basins (here interpreted as pull-apart-type basins) were formed and evolved (Fig. 3). The tectono-sedimentary features of the basins point to the idea that the main structures were active in several stages during the geological evolution of the periMediterranean area (see also Ballèvre et al. 2018). In particular, after the development of the Carboniferous-Early Permian dextral megashear, this axis became the locus of shear reactivations up to the main rifting in this sector of Pangaea during the Mid- to Late Permian to Middle Triassic.

The sedimentary and magmatic features categorise these intracontinental basins as sediment- or volcanic-dominated basins. At least three main stratigraphic gaps (i.e., the MidCarboniferous, Mid-Permian and Late Permian unconformities) can be identified in the Carboniferous-Permian record in most of the considered sectors, thus defining them as result of many different sedimentary cycles (e.g., the Kasimovian/Gzhelian to Sakmarian, Sakmarian-Artinskian to Roadian and Capitanian to Changhsian cycles). During Mid-Permian times the sharp change (i.e., the Mid-Permian event) from the previous organic-rich fluvial to marine successions to continental, often immature, red beds occurred in some sectors of the EVSZ, supporting tectonic reactivations and climatic changes. Moreover, in these times, still characterised by calc-alkaline products, the first appearance of an alkaline magmatism, typical in the Late Permian-Triassic successions, suggests a variation of the general geodynamic framework (e.g., the beginning of the inversion of the main shear movements in the megastructures).

In particular, we suggest not only that the EVSZ controlled the development of Late Carboniferous-Early Permian and Mid- to Late Permian basins but also that this major tectonic lineament continued its trans-tensional activity into the Triassic and controlled the opening of the Ligurian-Piedmont Ocean (Alpine Tethys) in a wide shear zone between the European and Adria-Africa continents (Coward and Dietric 1989; Nirta et al. 2007; Ballèvre et al. 2018) characterised by an overall sinistral-type shearing regime (Bortolotti et al. 1990). Finally, it is possible that these lines of weakness in the proposed configuration also helped the opening of the Neogene back-arc basins in the western Mediterranean Sea, which resulted in the present fragmentation of the Alpine Chain.

Acknowledgements The authors acknowledge the very constructive comments by Prof. Niko Froitzheim (University of Bonn) and by an anonymous reviewer, who allowed the improvement of the early 
version of the manuscript. Thanks are extended to Dr. Letizia Orti (Earth Sciences Department of the Florence University) for her help in drawing the stratigraphic columns. This research was supported by the University of Genova (PRA 2012 grant to Laura Gaggero and FRA 2018 grant to Franco M. Elter).

\section{References}

Abbate E, Fanucci F, Benvenuti M, Bruni P, Chiari M, Cipriani N, Falorni P, Fazzuoli M, Finocchiaro F, Morelli D, Moretti S, Nebbiai M, Pandeli E, Papini M, Pugliese N, Sagri M, Reale V, Vannucchi P, Venturi F (2005) Note illustrative della Carta Geologica d' Italia alla scala 1:50.000, Foglio n. 248 (La Spezia). APAT-Dipartimento Difesa del Suolo-Servizio Geologico d' Italia. S.EL.CA., Firenze. 204

Ait Chayeb EH, Youbi N, El-Boukhari A, Bouabdelli M, Amrhar M (1998) Le volcanisme permien et mésozoÏque inférieur du bassin d'Argana (Haut-Atlas occidental, Maroc): un magmatisme intraplaque associé à I'ouverture de I'Atlantique central. J Afr Earth Sc 26(4):499-519. https://doi.org/10.1016/S0899 $-5362(98) 00029-3$

Aldinucci M, Dallagiovanna G, Durand M, Gaggero L, Martini IP, Pandeli E, Sandrelli F, Tongiorgi M (2006) Late Paleozoic to Triassic continental deposits from Provence. Ligurian Alps and Tuscany. Field trip Guide-book. (18-21 September 2006). International meeting "Stratigraphy and Paleogeography of Late and Post-Hercynian basins in the Southern Alps, Tuscany and Sardinia (Italy)". Siena, pp 110

Aljinovic D, Isozaki Y, Sremac J (2008) The occurrence of giant bivalve Alatoconchidae from the Yabeina zone (Upper Guadalupian, Permian) in European Tethys. Gondwana Res 13:275-287. https://doi.org/10.1016/j.gr.2007.09.002

Arche A, Lopez-Gomez J (2005) Sudden changes in fluvial style across the Permian-Triassic boundary in the eastern Iberian Ranges, Spain: analysis of possible causes. Palaeogeogr Palaeoclimatol Palaeoecol 229:104-126. https://doi.org/10.1016/j.palae o.2005.06.033

Arthaud F, Matte P (1977) Late Paleozoic strike-slip faulting in southern Europe and northern Africa: result of a right lateral shear zone between the Appalachians and the Urals. Geol Soc Am Bull 88:1305-1320

Aubele K, Bachtadse V, Muttoni G, Ronchi A, Durand M (2012) A paleomagnetic study of Permian and Triassic rocks from the Toulon-Cuers Basin, SE France: evidence for intra-Pangaea block rotations in the Permian. Tectonics 31:1-14. https://doi. org/10.1029/2011TC003026

Bachtadse V, Aubele K, Muttoni G, Ronchi A, Kirscher U, Kent DV (2018) New early Permian paleopoles from Sardinia confirm intra-Pangaea mobility. Tectonophysics 749:21-34. https://doi. org/10.1016/j.tecto.2018.10.012

Baldelli C, Bigazzi G, Elter FM, Macera P (1987) Description of a permo-trias alkaline lamprophyre embedded into the micaschists of garnet-staurolite-kyanite grade of North-eastern Sardinia island. In: Sassi FP, Bourrouilh R (eds) IGCP Newsletter $\mathrm{n}^{\circ} 7$, pp 7-10

Ballèvre M, Manzotti P, Dal Piaz GV (2018) Pre-Alpine (Variscan) Inheritance: a key for the Location of the Future Valaisan Basin (Western Alps). Tectonics 37:786-817. https://doi. org/10.1002/2017TC004633

Barca S, Costamagna LG (2002) Analisi di facies e stratigrafia della successione permo?-triassica di Campumari-Coremò (Iglesiente, Sardegna SW). Bollettino della Società Geologica Italiana 122:25-45
Barca S, Costamagna LG (2003) The Upper Carboniferous S. Giorgio succession (Iglesiente, SW Sardinia): stratigraphy, depositional setting and evolution of a Post-Hercynian molassic basin. Bollettino della Società Geologica Italiana. Special Proceeding of the Scientific Meeting "Late Palaeozoic to Early Mesozoic events of Mediterranean Europe, and additional regional reports" (Siena, April 30 May 7 2001) Volume Speciale 2:89-98

Barca S, Costamagna LG (2005) Stratigrafia ed analisi di facies dei depositi permiani del Lago Mulargia (Sardegna sud-orientale): primi risultati. Geol Romana 38:11-17

Barca S, Costamagna LG (2006) Stratigrafia, analisi di facies ed architettura deposizionale della successione permiana di Guardia Pisano (Sulcis, Sardegna SW). Bollettino della Società Geologica Italiana 125:3-19

Bargossi GM, Di Battistini G, Montanini A (1993) The andesitic ignimbrites from the Lower Permian volcanic sequence in the Val di Cave and Val di Fregio area (Trento, N Italy). Miner Petrogr Acta 36:1-17

Beltrando M, Rubatto D, Compagnoni R, Lister G (2007) Was the Valaisan basin floored by oceanic crust? Evidence of Permian magmatism in the Versoyen unit (Valaisan domain, NW Alps). Ofioliti 32(2):85-99

Bergerat F, Angelier J, Andreasson P (2007) Evolution of paleostress fields and brittle deformation of the Tornquist Zone in Scania (Sweden) during Permo-Mesozoic and Cenozoic times. Tectonophysics 444:93-110. https://doi.org/10.1016/j.tecto.2007.08.005

Berra F, Tiepolo M, Caironi V, Siletto GB (2014) U-Pb zircon geochronology of volcanic deposits from the Permian basin of the Orobic Alps (Southern Alps, Lombardy): chronostratigraphic and geological implications. Geol Mag 152(3):429-443. https ://doi.org/10.1017/S0016756814000405

Bernoulli D, Ambrosi C, Scapozza C, Stockar R, Schenker FL, Gaggero L, Antognini M, Bronzini S (2018) Foglio 1373 Mendrisio (parte est) con parte Ovest del foglio Como. Atlante geologico della Svizzera 1:25:000, Note esplicative 152

Bonin B (1988) From orogenic to anorogenic environments: evidence from associated magmatic episodes. Schweiz Mineral Petrogr Mitt 68:301-311

Bonin B (1998) Orogenic to non-orogenic magmatic events: overview of the Late Variscan magmatic evolution of the Alpine Belt. Turk J Earth Sci 7(1998):133-143

Bonin B, Platevoet B, Vialette Y (1987) The geodynamic significance of alkaline magmatism in the Western Mediterranean compared with West Africa. In: Bowden P, Kinnaird J (eds) African Geology Reviews. Geological Journal 22:361-387. doi: 10.1002/ gj.3350220624

Bonin B, Azzouni-Sekkal A, Bussy F, Ferrag S (1998) Alkali-calcic and alkaline post-orogenic (PO) granite magmatism: petrologic constraints and geodynamic settings. Lithos 45:45-70. https:// doi.org/10.1016/S0024-4937(98)00025-5

Boote DRD, Clark-Lowes DD, Traut MW (1998) Palaeozoic petroleum systems of North Africa. In: MacGregor DS, Moody RTJ, ClarkLowes DD (eds) Petroleum geology of North Africa, 132nd edn. Geological Society, London, pp 7-68https://doi.org/10.1144/ GSL.SP.1998.132.01.02

Bortolotti V, Principi G, Treves B (1990) Mesozoic evolution of Western Tethys and the European/Iberia/Adria plate junction. Memorie della Società Geologica Italiana 45:393-407

Bortolotti V, Fazzuoli M, Pandeli E, Principi G, Babbini A, Corti S (2001) Geology of the central and eastern Elba Island. Italy Ofioliti 26(2):97-150. https://doi.org/10.4454/ofioliti.v26i2a.137

Bortolotti V, Chiari M, Marroni M, Pandolfi L, Principi G, Saccani E (2013) Geodynamic evolution of ophiolites from Albania and Greece (Dinaric-Hellenic belt): one, two, or more oceanic basins? Int J Earth Sci 10:783-811. https://doi.org/10.1007/ s00531-012-0835-7 
Bouaziz S, Barrier E, Soussi M, Turki MM, Zouari H (2002) Tectonic evolution of the northern African margin in Tunisia from paleostress data and sedimentary record. Tectonophysics 357:227253. https://doi.org/10.1016/S0040-1951(02)00370-0

Bourquin S, Durand M, Diez JB, Broutin J, Fluteau F (2007) The Permian-Triassic boundary and Early Triassic sedimentation in Western European basins: an overview. J Iber Geol 33(2):221236. https://doi.org/10.5209/JIGE.33912

Breitkreuz C, Cortesogno L, Gaggero L (2002) Crystal-rich mass flow deposits related to the eruption of a sublacustrine silicic cryptodome dome (Early Permian Collio Basin, Italian Alps). J Volcanol Geoth Res 114(3-4):373-390. https://doi.org/10.1016/ S0377-0273(01)00297-9

Buchs D (2013) Paleozoic to Triassic ocean opening and closure preserved in Central Iran: constraints from the geochemistry of meta-igneous rocks of the Anarak area. Lithos 172:173-267. https://doi.org/10.1016/j.lithos.2013.02.009

Buzzi L, Gaggero L (2007) Petrogenesis of post-orogenic Late Paleozoic andesite magmatism: a contribution from the Ligurian Alps (Italy). Per. Mineral., 76, 49-66, Special Issue "From Petrogenesis to Orogenesis", Gaggero L, Piccardo GB (eds) Doi: 10.2451/2007PM0008.

Buzzi L, Gaggero L (2008) Petrogenesis of post—orogenic Lower Permian andesites in southern Europe: insights into the collapse of the Variscan range. Geodin Acta 21(5/6):231-248. https://doi. org/10.3166/ga.21.273-290

Buzzi L, Gaggero L, Oggiano G (2008) The Santa Giusta Ignimbrite (NW Sardinia); a clue for the magmatic, structural and sedimentary evolution of a Variscan segment between Early Permian and Triassic. Ital J Geosci 127:683-695

Cabella R, Cortesogno L, Dallagiovannna G, Vannucci R, Vanossi M (1988) Vulcanismo, sedimentazione e tettonica nel Brianzonese ligure esterno durante il Permo-Carbonifero. Atti Ticinensi di Scienze della Terra 40:269-326

Cadel G, Cosi M, Pennacchioni G, Spalla MI (1996) A new map of the Permo-Carboniferous cover and Variscan metamorphic basement in the central Orobic Alps, Southern Alps-Italy: structural and stratigraphical data. Mem Sci Geol 48:1-53

Capuzzo N, Bussy F (2001) Synsedimentary volcanism in the Late Carboniferous Salvan-Dorénaz Basin (Western Alps). Nat Bresciana Ann Mus Civ Sc Nat Brescia 25:203-211

Carosi R, Montomoli C, Tiepolo M, Frassi C (2012) Geochronological constraints on post-collisional shear zones in the Variscides of Sardinia (Italy). Terra Nova 24(1):42-51

Carrigan CW, Mukasa SB, Haydoutov I, Kolcheva K (2006) Neoproterozoic magmatism and Carboniferous high-grade metamorphism in the Sredna Gora Zone, Bulgaria: An extension of the Gondwana-derived Avalonian-Cadomian belt? Precambr Res 147:404-416. https://doi.org/10.1016/j.precamres.2006.01.026

Casini L, Cuccuru S, Maino M, Oggiano G, Tiepolo M (2012) Emplacement of the Arzachena Pluton (Corsica-Sardinia Batholith) and the geodynamics of incoming Pangaea. Tectonophysics 544-545:31-49

Casini L, Cuccuru S, Puccini A, Oggiano G, Rossi P (2015) Evolution of the Corsica-Sardinia Batholith and late-orogenic shearing of the Variscides. Tectonophysics 646:65-78. https://doi. org/10.1016/j.tecto.2015.01.017

Cassinis G (1988) Carta geologica dei depositi continentali permiani a Sud dell'Adamello. Atti Ticinensi Scienze Terra, Pavia, p 31

Cassinis G, Perotti CR (1994) Interazione strutturale permiana tra la linea delle Giudicarie ed i bacini di Collio, Tione e Tregiovo (Sudalpino centrale, NE Italia). Bollettino della Società Geologica Italiana 112:1021-1036

Cassinis G, Ronchi A (2002) The (Late-) Post-Variscan continental successions of Sardinia. Rendiconti della Società Paleontologica Italiana 1:169-176
Cassinis G, Cortesogno L, Gaggero L, Ronchi A, Valloni R (1996) Stratigraphic and petrographic investigations into the PermianTriassic continental sequences of Nurra (NW Sardinia). Quad Geol Iber 21:149-169

Cassinis G, Cortesogno L, Gaggero L, Ronchi A, Valloni R (1997a) Stratigraphic and petrographic investigations into the PermoTriassic continental sequences of Nurra (NW Sardinia). Cuad Geol Iber 21:149-169

Cassinis G, Perotti CR, Venturini C (1997b) Examples of late Hercynian transtensional tectonics in the Southern Alps (Italy). In: Dickins J (ed) Late Paleozoic and Early Mesozoic Circum- Pacific events and their global correlation. Cambridge Univ Press, Cambridge, pp 41-50

Cassinis G, Avanzini M, Cortesogno L, Dallagiovanna G, Di Stefano P, Gaggero L, Gullo M, Neri C, Ronchi A, Seno S, Vanossi M, Venturini C (1998) Synthetic upper Paleozoic correlation charts of selected Italian areas. Atti Ticinensi Scienze della Terra 40:65-120

Cassinis G, Cortesogno L, Gaggero L, Ronchi A, Sarria E, Serri R, Calzia P (2003a) Reconstruction of igneous, tectonic and sedimentary events in the latest Carboniferous-Early Permian Seui Basin (Sardinia, Italy), and evolutionary model. Bollettino della Società Geologica Italiana 2:99-117 (With geological map)

Cassinis G, Durand M, Ronchi A (2003b) Permian-Triassic continental sequences of Northwest Sardinia and South Provence: stratigraphic correlations and palaeogeographical implications. Bollettino della Società Geologica Italiana 2:119-129

Cassinis GL Cortesogno GL, Perotti C, Ronchi A (2007) Volcanic product from the early Permian Collio basin (Southern Alps) and their geodynamic implications, Periodico di Mineralogia, Special Issue From petrogenesis to orogenesis, Gaggero L, Piccardo GB (eds) 76:25-47, Doi: 10.2451/2007/PM0007

Cassinis G, Cortesogno L, Gaggero L, Perotti CR, Buzzi L (2008) Permian to Triassic geodynamic and magmatic evolution of the Brescian Alps (eastern Lombardy, Italy). In: Cassinis G (Guest Ed) Special Section: stratigraphy and palaeogeography of lateand post-Hercynian basins in the Southern Alps, Tuscany and Sardinia (Italy). Bollettino della Società Geologica Italiana (Italian J Geosciences) 127(3):501-518

Cassinis G, Perotti CR, Ronchi A (2012) Permian continental basins in the Southern Alps (Italy) and peri-mediterranean correlations. Int J Earth Sci (Geologische Rundschau) 101:129-157. https:// doi.org/10.1007/s00531-011-0642-6

Cassinis G, Perotti C, Santi G (2018) Post-Variscan Verrucano-like deposits in Italy, and the onset of the alpine tectono-sedimentary cycle. Earth-Sci Rev 185:476-497. https://doi.org/10.1016/j. earscirev.2018.06.021

Catalan JRM (2011) Are the oroclines of the Variscan belt related to late Variscan strike-slip tectonics? Terra Nova 23:241-247. https ://doi.org/10.1111/j.1365-3121.2011.01005.x

Cocherie A, Rossi Ph, Fanning CM, Guerrota C (2005) Comparative use of TIMS and SHRIMP for U-Pb zircon dating of A-type granites and mafic tholeiitic layered complexes and dykes from the Corsican Batholith (France). Lithos 82:185-219. https://doi. org/10.1016/j.lithos.2004.12.016

Corsi B, Elter FM, Pandeli E, Sandrelli F (2001) Caratteri strutturali del Gruppo del Verrucano (Unità di Monticiano-Roccastrada) nella Toscana meridionale ed insulare. Atti Ticinensi di Scienze della Terra 42:47-58

Corsini M, Ruffet G, Caby R (2004) Alpine and late-hercynian geochronological constraints in the Argentera Massif (Western Alps). Eclogae Geologicae Helveticae 97:3-15. https://doi. org/10.1007/s00015-004-1107-8

Cortesogno L, Gaggero L (2011) Il vulcanismo Permo-Triassico. In: Note illustrative al Foglio "99-Iseo", Carta Geologica Regionale 1: 50.000. Regione Lombardia 
Cortesogno L, Gaggero L, Lucchetti G (1987) Phosphate mineralizations in a permo-triassic sequence (Giogo di Toirano, Italy). Neues Jahrb Mineral Monatsh H7:305-313

Cortesogno L, Dallagiovanna G, Vannucci R, Vanossi M (1988) Volcanisme, sedimentation et tectonique pendant le Permo-Carbonifère en Briançonnais ligure: une revue. Eclogae Geol Helv 81:487-510. https://doi.org/10.5169/seals-166190

Cortesogno L, Dallagiovanna G, Gaggero L, Vanossi M (1992) Late variscan intermediate volcanism in the Ligurian Alps. IGCP N. 276. Newsl Contrib Geol Italy 5:241-262

Cortesogno L, Dallagiovanna G, Gaggero L, Vanossi M (1993) Elements of the Palaeozoic history of the Ligurian Alps. In: von Raumer JF, Neubauer F (eds) Pre-Mesozoic Geology in the Alps. Springer, Berlin, pp 257-277

Cortesogno L, Dallagiovanna G, Gaggero L, Seno S, Vanossi M (1995) Nuovi dati sul basamento e sul tegumento carbonifero dell'Unità di Mallare (Brianzonese intermedio - interno, Alpi Liguri). Atti Ticinensi di Scienze della Terra. Serie Speciale 3, 65-82. Proceedings annual meeting 1994 Gruppo Alpi-CNR.

Cortesogno L, Di Stefano L, Gaggero L, Seno S (1996) Granodiorites in the Eastern Briançonnais volcano-sedimentary Permian sequences: Structural, petrographic and geochemical characterization. Atti Ticinensi di Scienze della Terra, Serie Speciale. Proceedings della riunione annuale 1995 del Gruppo Alpi-CNR, 4:87-101

Cortesogno L, Cassinis G, Dallagiovanna G, Gaggero L, Oggiano G, Ronchi A, Seno S, Vanossi M (1998a) The Variscan postcollisional volcanism in Late Carboniferous-Permian sequences of Ligurian Alps, Southern Alps and Sardinia (Italy): a synthesis. Lithos 45(1-4):305-328. https://doi.org/10.1016/S0024 $-4937(98) 00037-1$

Cortesogno L, Dallagiovanna G, Gaggero L, Seno S, Vanossi M (1998b) Tettonica e vulcanismo tardo-Paleozoici nel dominio prepiemontese delle Alpi Liguri: la testimonianza della successione del Colle Scravaion. Atti Ticinensi di Scienze della Terra $7: 17-26$

Cortesogno L, Fiorini E Gaggero L, Molina M, Ronchi A (1998c) New stratigraphic and petrographic data on the Permian Tione basin (Lower Val Rendena, Trentino, Italy). Atti Ticinensi di Scienze della Terra. Proceedings annual meeting 1997 del Gruppo AlpiAppennino-CNR. 7:125-138

Cortesogno L, Gaggero L, Ronchi A, Yanev S (2004a) Late orogenic magmatism and sedimentation within Late Carboniferous to Early Permian basins in the Balkan terrane (Bulgaria): geodynamic implications. Int J Earth Sci 93(4):500-520. https://doi. org/10.1007/s00531-004-0410-y

Cortesogno L, Gaggero L, Yanev S (2004b) Anorogenic volcanism in the Triassic sequences at the boundary of the Moesian plate. Geodin Acta 17:55-69. https://doi.org/10.3166/ga.17.55-69

Costamagna LG (2011a) Alluvial, aeolian and tidal deposits in the Lower to Middle Triassic "Buntsandstein" of NW Sardinia (Italy): a new interpretation of the Neo-Tethys transgression. Zeitschrift der Deutschen Gesellschaft für Geowissenschaften (ZDGG) Band 163(Heft 2):165-183. https://doi. org/10.1127/1860-1804/2012/0163-0165

Costamagna LG (2011b) Facies analysis, stratigraphy and petrographic data from the Permian-Middle Triassic Cala Bona - Il Cantaro Rock sections (Alghero, NW Sardinia, Italy): contribution to the post-Variscan Nurra basin evolution. Atti Società Toscana di Scienze Naturali, Serie A 116:53-70

Costamagna LG (2018) The lower Triassic continental to transitional deposits of the Maritime Alps (NW Italy): stratigraphic and sedimentological features. J Mediterr Earth Sci 10(2018):135-139

Costamagna LG (2019) The carbonates of the post-Variscan basins of Sardinia: the evolution from Carboniferous-Permian humidpersistent to Permian arid-ephemeral lakes in a morphotectonic framework. Geol Mag. https://doi.org/10.1017/S001675681 9000232

Costamagna LG, Barca S (2002) The "Germanic" Triassic of Sardinia (Italy): a stratigraphic, depositional and paleogeographic review. Riv Ital Paleontol Stratigr 108(1):67-100

Costamagna LG, Barca S (2008) Depositional architecture and sedimentology of the Tuppa Niedda Conglomerates (Late Carboniferous, Arburese, SW Sardinia, Italy). Bollettino della Società Geologica Italiana (It Jour Geosc) 128(3):625-636

Costamagna LG, Barca S, Del Rio M, Pittau P (2000) Stratigrafia, analisi di facies deposizionale e paleogeografia del Trias del Sarcidano-Gerrei (Sardegna SE). Bollettino della Società Geologica Italiana 119(2):473-496

Costantini A, Elter FM, Pandeli E, Sandrelli F (1998) Geologia dell'area di Iano (Toscana meridionale, Italia). Bollettino Società Geologica Italiana 117:187-218

Coward M, Dietrich D (1989) Alpine tectonics-an overview, 45th edn. Geological Society, London, pp 1-29

Dallagiovanna G, Gaggero L, Maino M, Seno S, Tiepolo M (2009) $\mathrm{U}-\mathrm{Pb}$ zircon ages for post-Variscan volcanism in the Ligurian Alps (Northern Italy). J Geol Soc Lond 166(2009):1-14. https:// doi.org/10.1144/0016-76492008-027

Decarlis A, Dallagiovanna G, Lualdi A, Maino M, Seno S (2013) Stratigraphic evolution in the Ligurian Alps between Variscan heritages and the Alpine Tethys opening: A review. Earth Sci Rev 125(2013):43-68. https://doi.org/10.1016/j.earsc irev.2013.07.001

Decarlis A, Fellin MG, Maino M, Ferrando S, Manatschal G, Gaggero L, Seno S, Stuart FM, Beltrando M (2017) Tectono-thermal evolution of a distal rifted margin: constraints from the Calizzano Massif (Prepiedmont-Briançonnais domain, Ligurian Alps). Tectonics 36(12):3209-3228. https://doi.org/10.1002/2017TC0046 34

Derder MEM, Henry B, Amenna M, Bayou B, Djellit H, Guemache MA, Hemmi A (2009) New structural implications for the central Sahara (Algeria), from the revisited Upper Carboniferous "Hassi Bachir" Formation: Paleomagnetic constraints. Tectonophysics 462(1/4):69-76. https://doi.org/10.1016/j.tecto.2008.09.012

Derder MEM, Henry B, Ouabadi A, Amenna M, Bayou B, Maouche S, Boubdallah H, Ayache M, Bediaf M (2014) First Moscovian paleomagnetic pole, age-constrained by a fold test, in Ezzane area in the Murzuq basin (Algeria, stable Africa): Improvement of the Gondwana APWP. Castle Meeting New trends on Paleo Rock and Environmental Magnetism, Évora, p 2014

Deroin JP, Bonin B, (2003) Late Variscan Tectonomagmatic activity in Western Europe and surrounding areas: the Mid-Permian Episode. Bollettino della Società Geologica Italiana, Vol Spec 2, Special Proceeding of the Scientific Meeting "Late Palaeozoic to Early Mesozoic events of Mediterranean Europe, and additional regional reports" (Siena, April 30-May 7 2001), 169-184

Deroin JP, Bonin B, Broutin J, Cabanis B, Châteauneuf JJ, Amotte R, Durand M, Gand G (2001) The Permian of Southern France: an overview Permian Continental Deposits of Europe and Other Areas. Regional Reports and Correlations. Proc. Intern. Field Conf. on «the Continental Permian of the Southern Alps and Sardinia (Italy). In: Cassinis G (Ed) Regional Reports and General Correlations», 15-25 September (1999), Brescia, Italy. «Natura Bresciana», Ann Mus Civ Sc Nat, Brescia, Monogr, 25:189-202

Dewey JF (1988) Lithospheric stress, deformation, and tectonic cycles: the disruption of Pangaea and the closure of Tethys. In: AudleyCharles MG, Hallam A (eds) Gondwana and Tethys, 37th edn. Geological Society, London, pp 23-40.https://doi.org/10.1144/ GSL.SP.1988.037.01.03

Di Battistini G, Gallo F, Giammetti F, Vernia L (1989) Permian andesites from Val d'Isarco and Val di Funes volcanic sequence (Bolzano, northern Italy). Mineral Petrogr Acta 32:123-137 
Dias R, Moreira N, Ribeiro A, Basile C (2017) Late Variscan deformation in the Iberian Peninsula; a late feature in the LaurentiaGondwana dextral collision. Int J Earth Sci 106(2):549-567. https://doi.org/10.1007/s00531-016-1409-x

Dornsiepen UF, Manutsoglu E, Mertmann D (2001) Permian-Triassic paleogeography of the external Hellenides. Palaeogeogr Palaeoclimatol Palaeoecol 172:327-338. https://doi.org/10.1016/S0031 $-0182(01) 00307-8$

Durand M (2006) The problem of the transition from the Permian to the Triassic Series in southeastern France: comparison with other Peritethyan regions. In: Lucas G, Cassinis G, Schneider JW (eds) Non-marine permian biostratigraphy and biochronology, 265th edn. Geological Society Special Publication, London, pp 281296.https://doi.org/10.1144/GSL.SP.2006.265.01.13

Durand M (2008) Permian to Triassic continental successions in southern Provence (France): an overview. Ital J Geosci 127:697-716

Durand M, Caron JP, Hagdorn H, Diez-Ferrer JB (2011) Triassic of southeast France (Provence: Var and Alpes-Maritimes). PanEuropean Correlation of the Triassic-8th International Field Workshop. Printed by AGPT (Association des Géologues du Permien et du Trias), pp 66

Edel JB, Schulmann K, Lexa O, Diraison M, Géraud Y (2015) Permian clockwise rotations of the Ebro and Corso-Sardinian blocks during Iberian-Armorican oroclinal bending: preliminary paleomagnetic data from the Catalan Coastal Range (NE Spain). Tectonophysics 657:172-186. https://doi.org/10.1016/j.tecto .2015.07.002

Eichhorn R, Loth G, Holl R, Finger F, Schermaier A, Kennedy A (2000) Multistage Variscan magmatism in the Central Tauern Window (Austria) unveiled by U-Pb SHRIMP zircon data. Contrib Miner Petrol 139:418-435. https://doi.org/10.1007/s0041 00000145

Elter FM, Pandeli E (1990) Alpine and hercynian orogenic phases in the basement rocks of the Northern Apennines (Larderello geothermal-field, Southern Tuscany, Italy). Eclogae Geol Helv 83(2):241-264

Elter FM, Pandeli E (1991) Structural features of the metamorphic Paleozoic- Triassic sequences in deep geothermal drillings of the Monte Amiata Area (SE Tuscany, Italy). Bollettino della Società Geologica Italiana 110:511-522

Elter FM, Padovano M, Kraus KR (2010) The emplacement of Variscan HT metamorphic rocks linked to the interaction between Gondwana and Laurussia: Structural constraints in NE Sardinia (Italy). Terra Nova 22:369-377. https://doi.org/10.111 1/j.1365-3121.2010.00959.x

Elter FM, Elter P, Eva C, Eva E, Kraus RK, Padovano M, Solarino S (2011) Strike-slip geometry inferred from the seismicity of the Northern-Central Apennines (Italy). J Geodyn 52:379-388. https ://doi.org/10.1016/j.jog.2011.03.003

Frings K, Lutz R, de Wall H, Warr LN (2004) Coalification history of the Stephanian Ciñera- Matallana pull- part basin, NW Spain: combining anisotropy of vitrinite reflectance and thermal modelling. Int J Earth Sci 93:92-106. https://doi.org/10.1007/s0053 1-003-0370-7

Gaggero L, Cortesogno L, Bertrand JM (2004) The pre-Namurian basement of the Ligurian Alps: a review of the lithostratigraphy, pre-Alpine metamorphic evolution, and regional comparisons. Periodico Mineralogia, 73. Spec Issue 2:85-96

Gaggero L, Oggiano G, Buzzi L, Slejko F, Cortesogno L (2007) PostVariscan mafic dikes from the Late orogenic collapse to the Tethyan rift: evidence from Sardinia. Ofioliti 32(1):15-37

Gaggero L, Gretter N, Langone A, Ronchi A (2017) U-Pb geochronology and geochemistry of late Palaeozoic volcanism in Sardinia (southern Variscides). Geosci Front 8:1263-1284. https://doi. org/10.1016/j.gsf.2016.11.015
Genier F, Bussy F, Epard JL, Baumgartner L (2008) Water-assisted migmatization of metagraywackes in a Variscan shear zone, Aiguilles-Rouges massif, western Alps. Lithos 102:575-597. https://doi.org/10.1016/j.lithos.2007.07.024

Gras DG, Zarza AMA (2003) Reworked calcretes: their significance in the reconstruction of alluvial sequences (Permian and Triassic, Minorca, Balearic Islands, Spain). Sediment Geol 158:299-319

Gretter N, Ronchi A, Lopez-Gòmez JL, Arche A, De la Horra R, Barrenechea J, Lago M (2015) The Late Paleozoic-Early Mesozoic from the Catalan Pyrenees (Spain): $60 \mathrm{Myr}$ of environmental evolution in the frame of the western peri-Tethyan palaeogeography. Earth-Sci Rev 150:2-26. https://doi.org/10.1016/j.earsc irev.2015.09.001

Gutiérrez-Alonso G, Fernandez-Suarez J, Weil AB (2004) Orocline trigged lithospheric delamination. Geol Soc Am 383:121-130

Gutiérrez-Alonso G, Fernandez-Suarez J, Weil AB, Murphy JB, Nance RD, Corfu F, Johnston ST (2008) Self-subduction of the Pangaean global plate. Nat Geosci 1:549-553. https://doi. org/10.1038/ngeo250

Gutiérrez-Alonso G, Collins AS, Fernández-Suárez J, Pastor-Galán D, González-Clavijo E, Jourdan F, Johnston ST (2015) Dating of lithospheric buckling: 40Ar/39Ar ages of syn-orocline strike-slip shear zones in northwestern Iberia. Tectonophysics 643:44-54. https://doi.org/10.1016/j.tecto.2014.12.009

Handy MR, Zingg A (1991) The tectonic and rheological evolution of an attenuated cross section of the continental crust: Ivrea crustal section, southern Alps, northwestern Italy and southern Switzerland. Geol Soc Am Bull 103:236-253. https ://doi.org/10.1130/0016-7606(1991)103\%3c0236:TTARE $\mathrm{O} \% 3 \mathrm{e} 2.3 . \mathrm{CO} ; 2$

Hatcher RD (1995) Structural geology: principles, concepts and problems. Prentice-Hall International, Upper Saddle Rive, pp 1-516

Henk A, Leander F, Teufel S, Oncken O (1997) Magmatic underplating, extension and crustal reequilibration: Insights from a crosssection through the Ivrea Zone and Strona-Ceneri Zone, Northern Italy. J Geol 105:367-377. https://doi.org/10.1086/515932

Henry B, Derder MEM, Amenna M, Maouche S, Bayou B, Ouabadi A, Bouabdallah H, Beddiaf M, Ayache M, Bestandji R (2014) Paleomagnetic dating of continental geological formations: strong diachronism evidenced in the Saharan platform and geodynamical Implications. J Afr Earth Sc 99:353-362. https://doi. org/10.1016/j.jafrearsci.2014.02.010

Hmich D, Schneider JW, Saber H, Voigt S, El Wartiti M (2006) New continental Carboniferous and Permian faunas of Morocco: implications for biostratigraphy, palaeobiogeography and palaeoclimate. In: Lucas SG, Cassinis G, Schneider JW (eds) Nonmarine permian biostratigraphy and biochronology, 265th edn. Geological Society of London Special Publications, London, pp 297-324https://doi.org/10.1144/GSL.SP.2006.265.01.14

Hymmerkus F, Anders B, Reischmann T, Kostopoulus D (2007) Gondwana-derived terranes in the northern Hellenides. In: Hatcher RD, Carlson MP, McBride Martinez-Catalan JR (eds) Framework of Continental Crust, 200th edn. Geological Society of America Memoirs, Boulder, pp 379-390 https://doi. org/10.1130/2007.1200(19)

Hynes A (1990) Two-stage rifting of of Pangaea by two different mechanism. Geology 18:323-326. https://doi.org/10.1130/00917613(1990)018\%3c0323:TSROPB\%3e2.3.CO;2

Khessibi M (1985) Etude sédimentologique des affleurements permiens du Djebel Tebaga de Médenine (Sud Tunisie). Bull Cent Rech Explor Prod Elf-Aquitaine Pau 9(2):427-464

Kilani-Mazraoui F, Razgallah-Gargouri S, Mannai-Tayech B (1990) The Permo-Triassic of Southern Tunisia-biostratigraphy and palaeoenvironment. Rev Palaeobot Palynol 66:273-275. https:// doi.org/10.1016/0034-6667(90)90043-I 
Knight JA, Burger K, Bieg G (2000) The pyroclastic tonsteins of the Sabero Coalfield, north-western Spain, and their relationship to the stratigraphy and structural geology. Int J Coal Geol 44:187226. https://doi.org/10.1016/S0166-5162(00)00011-2

Lago M, Arranz E, Pocovi A, Galé C (2004) Permian magmatism and basin dynamics in the southern Pyrenees: a record of the transition from late Variscan transtension to early Alpine extension. Geol Soc Lond 223:439-464. https://doi.org/10.1144/GSL. SP.2004.223.01.19

Landi Degl'Innocenti V, Pandeli E, Mariotti Lippi M, Cioppi E (2008) The Carboniferous-Permian succession of the Pisani Mountains (Tuscany, Italy): preliminary data from the De Stefani collection (Natural History Museum of Florence). Bollettino della Società Geologica Italiana 127:545-558

Lapierre H, Basile C, Dupuis V (1999) Basaltes et trachytes permiens de l'Esterel (SE France); une serie tholeiitique transitionnelle epanchée pendant l'amincissement lithospherique. Bulletin de la Société Géologique de France 170(2):253-265

Leroy S, Cabanis B (1993) Le volcanisme permien du bassin de Toulon: un jalon septentrional du volcanisme permien de l'Ouest mèditerranéen. Géologie de la France 2(1992):57-66

Lopez-Gomez JL, Arche A, Marzo M, Durand M (2005) Stratigraphical and palaeogeographical significance of the continental sedimentary transition across the Permian-Triassic boundary in Spain. Palaeogeogr Palaeoclimatol Palaeoecol 229(1-2):3-23. https://doi.org/10.1016/j.palaeo.2004.11.028

López-Gómez J, Alonso-Azcárate J, Arche A, Arribas J, Fernández Barrenechea J, Borruel-Abadía V, Bourquin S, Cadenas P, Cuevas J, De la Horra R, Bienvenido Díez J, Escudero-Mozo MJ, Fernández-Viejo G, Galán-Abellán B, Galé C, Gaspar-Escribano J, Gisbert Aguilar J, Gómez-Gras D, Goy A, Gretter N, Heredia Carballo N, Lago M, Lloret JL, Javier Márquez L, MárquezAliaga A, Martín-Algarra A, Martín-Chivelet J, Martín-González F, Marzo M, Mercedes-Martín R, Ortí F, Pérez-López A, PérezValera F, Pérez-Valera JA, Plasencia P Ramos E, RodríguezMéndez L, Ronchi A, Salas R, Sánchez-Fernández D, Moya S, Sopeña Y, Suárez-Rodríguez A, Tubía Á, Ubide JM, Blas Valero Garcés T, Vargas H, Viseras C (2019) Permian-Triassic Rifting Stage In: C Quesada, JT Oliveira (eds.) The Geology of Iberia: a geodynamic approach, regional geology reviews, 29-111, doi: 10.1007/978-3-030-11295-0_3

Maino M, Dallagiovanna G, Gaggero L, Seno S, Tiepolo M (2012) $\mathrm{U}-\mathrm{Pb}$ zircon geochronological and petrographic constraints on late to post-collisional Variscan magmatism and metamorphism in the Ligurian Alps Italy. Geol J 47(6):632-652. https://doi. org/10.1002/gj.2421

Maino M, Gaggero L, Langone A, Seno S, Fanning M (2019) CambroSilurian magmatisms at the northern Gondwana margin (Penninic basement of the Ligurian Alps). Geosci Front 10:315-330. https://doi.org/10.1016/j.gsf.2018.01.003

Malavielle J, Guihot P, Costa S, Lardeaux JM, Gardien V (1990) Collapse of a thickened crust in the French Massif Central: Mont Pilat extensional shear zone and Saint-Etienne Upper Carboniferous basins. Tectonophysics 177:139-149. https://doi. org/10.1016/0040-1951(90)90278-G

Marocchi M, Morelli C, Mair V, Klötzli U, Bargossi GM (2008) Evolution of large silicic magma systems: New U-Pb zircon data on the NW permian athesian volcanic group (Southern Alps, Italy). J Geol 116:480-498. https://doi.org/10.1086/590135

Marotta AM, Spalla I (2007) Permian-Triassic high thermal regime in the Alps: results of Late Variscan collapse or continental rifting? Validation by numerical modelling. Tectonics 26(4):26-37. https ://doi.org/10.1029/2006TC002047

Martínez Catalán JR (2011) Are the oroclines of the Variscan belt related to late Variscan strike-slip tectonics? Terra Nova 23(4):241-247
Martini IP, Rau A, Tongiorgi M (1986) Syntectonic sedimentation in a Middle Triassic Rift Northern Apennines, Italy. Sediment Geol 47(1986):191-219. https://doi.org/10.1016/00370738(86)90084-9

McCann T, Kiersnowski H, Krainer K, Vozarova A, Peryt TM, Oplustil S, Stollhofen H, Schneider J, Wetzel A, Buolvain F, Dusar M, Torok A, Haas J, Tait J, Korner F (2008) Permian. In: McCann T (ed) The geology of Central Europe. 1: Precambrian and Paleozoic. The Geological Society, London, pp 531-597

Mugnier JL, Cannic S, Lapierre H (2008) Les tholéites du domaine Valaisan (Complexe du Versoyen, Alpes occidentales): un magma Carbonifère dans un petit basin océanique. Bulletin de la Société Géologique de France 179(4):357-368. https://doi. org/10.2113/gssgfbull.179.4.357

Murphy JB, Waldron JWF, Kontak DJ, Pe-Piper G, Piper DJW (2011) Minas fault Zone: Late Paleozoic history of an intracontinental orogenic transform fault in the Canadian Appalachians. J Struct Geol 33:312-328. https://doi.org/10.1016/j. jsg.2010.11.012

Muttoni G, Gaetani M, Kent DV, Sciunnach D, Angiolini L, Berra F, Garzanti E, Mattei M, Zanchi A (2009) Opening of the NeoTethys Ocean, and the Pangaea B to Pangaea a trasformation during the Permian. GeoArabia 14(4):17-48

Neubauer F, Handler R (2000) Variscan orogeny in the Eastern Alps and Bohemian Massif: how do these units correlate? Mitteilungen der Österreichischen Geologischen Gesellschaft 92:35-59

Nicholls IA, Lorenz V (1973) Origin and crystallization history of Permian tholeiites from the Saar-Nahe trough, SW Germany. Contrib Miner Petrol 40:334-337

Nirta G, Principi G, Vannucchi P (2007) The Ligurian Units of Western Tuscany (Northern Apennines): insights on the influence of pre-existing weakness zones during ocean closure. Geodin Acta 20:71-97. https://doi.org/10.3166/ga.20.71-97

Olsen PE, Kent DV, Fowell SJ, Schlische RW, Withjack MO, Le Tourneau M (2000) Implications of a comparison of the stratigraphy and depositional environments of the Argana (Morocco) and Fundy (Nova Scotia, Canada) Permian-Jurassic basins. In: Oujidi M, Et-Touhami M (eds) Le Permien et le Trias du Maroc: Actes de La Première Reunion du Groupe Marocain du Permien et du Trias. HILAL IMPRESSION, Oujda, pp 165-183

Padovano M, Dorr W, Elter FM, Gerdes A (2014) The East Variscan Shear Zone: Geochronological constraints from the Capo Ferro area (NE Sardinia, Italy). Lithos 196-197:27-41. https://doi. org/10.1016/j.lithos.2014.01.015

Padovano M, Elter FM, Pandeli E, Franceschelli M (2011) The East Variscan Shear Zone: new insights into its role in the Late Carboniferous collision in southern Europe. Int Geol Rev 54(8):957970. https://doi.org/10.1080/00206814.2011.626120

Pamic J, Jurkovic I (2002) Paleozoic tectonostratigraphic units of the northwest and central Dinarides and the adjoining South Tisia. Int J Earth Sci 91:538-554. https://doi.org/10.1007/s0053 1-001-0229-8

Pandeli E (1998) Permo-Triassic siliciclastic sedimentation in the Northern Apennines: new data from the Iano metamorphic inlier (Florence). Memorie della Società Geologica Italiana 53:185-206

Pandeli E (2002) Sedimentary-tectonic evolution of the Tuscan area (Northern Apennines, Italy) from Late "Autunian" to Carnian. Bollettino della Società Geologica Italiana 1-2002:251-262

Pandeli E, Pasini M (1990) Fusulinidi permiani nella successione metamorfica del sottosuolo del M. Amiata, Toscana meridionale (Italia), Rivista Italiana di Paleontologia e Stratigrafia 96(1):3-20

Pereira MF, Apraiz A, Chichorro M, Silva JB, Amstrong RA (2010) Exhumation of high-pressure rocks in northern Gondwana during Early Carboniferous (Coimbra-Cordoba shear zone, SW Iberia Massif): tectono-thermal analysis and U-Th-Pb SHRIMP in situ 
zircon geochronology. Gondwana Res 17:440-460. https://doi. org/10.1016/j.gr.2009.10.001

Pereira MF, Castro A, Chichorro M, Fernández C, Díaz-Alvarado J, Martí J, Rodríguez C (2014) Chronological link between deepseated processes in magma chambers and eruptions: PermoCarboniferous magmatism in the core of Pangaea (Southern Pyrenees). Gondwana Res 25:290-308. https://doi.org/10.1016/j. gr.2013.03.009

Perini G, Cebria JM, Lopez-Ruiz J, Doblas M (2004) Carboniferous-Permian mafic magmatism in the Variscan belt of Spain and France: implications for mantle sources. Geol Soc Lond Spec Publ 223(1):415-438. https://doi.org/10.1144/GSL. SP.2004.223.01.18

Pochat S, Van Den Driessche J, Mouton V, Guillocheau F (2005) Identification of Permian palaeowind direction from wave-dominated lacustrine sediments (Lodève Basin, France). Sedimentology 52(4):809-825. https://doi.org/10.1111/j.1365-3091.2005.00697 .X

Pohl F, Froitzheim N, Obermuller G, Tomaschek F, Schroder O, Nagel TJ, Sciunnach D, Heuser A (2018) Kinematics and age of syn-intrusive detachment faulting in the Southern Alps: evidence for Early Permian Crustal extension and implications for the Pangaea A Versus B Controversy. Tectonics. https://doi. org/10.1029/2018TC004974

Poli G, Ghezzo C, Conticelli S (1989) Geochemistry of granitic rocks from the Hercynian Sardinia-Corsica batholith: Implication for magma genesis. Lithos 23(4):247-266. https://doi. org/10.1016/0024-4937(89)90038-8

Popescu BM (1995) Algeria. In: H Kulke (ed.) Regional petroleum geology of the world, P II Beitr Regional Geol D Erde, Gebruder Borntraeger Verlagsbuchhandlung, D-70176 Stuttgart, Bd 22:13-34

Pressler RE, Schneider MS, Holm DK, Geissman DK (2007) Pervasive horizontal fabric and rapid vertical extrusion: Lateral overturning and margin sub-parallel flow of deep crustal migmatites, northeastern Bohemian Massif. Tectonophysics 443:19-36. https:// doi.org/10.1016/j.tecto.2007.07.003

Prost AE, Becq-Giraudon JF (1989) Evidence for Mid-Permian compressive tectonics in western Europe supported by a comparison with the Alleghenian geodynamic evolution. Tectonophysics 169:333-340. https://doi.org/10.1016/0040-1951(89)90095-4

Rau A (1990) Evolution of the Tuscan Domain between the Upper Carboniferous and Mid-Triassic: a new hypothesis. Bollettino della Società Geologica Italiana 109:231-238

Rau A (1993) Il Paleozoico toscano: da segmento della catena varisica sud-europea a margine passivo alpidico peri-adriatico. Memorie della Società Geologica Italiana 49:325-334

Rau A, Tongiorgi M (1974) Geologia dei Monti Pisani a sud-est della Valle del Guappero. Memorie della Società Geologica Italiana 12:227-408

Rau A, Tongiorgi M (1980) Alcune ipotesi sulla storia pre-giurassica del futuro margine continentale nord-appenninico. Memorie della Società Geologica Italiana 21:23-31

Raulin C, Frizon de Lamotte D, Bouaziz S, Khomsi S, Mouchot N, Ruiz G, Guillocheau F (2011) Late Triassic-early Jurassic block tilting along E-W faults, in southern Tunisia: New interpretation of the Tebaga of Medenine. J Afr Earth Sc 61(1):94-104. https ://doi.org/10.1016/j.jafrearsci.2011.05.007

Rodrìguez-Méndez L, Cuevas J, Tubìa JM (2016) Post-Variscan basin evolution in the central Pyrenees: Insights from the StephanianPermian Anayet Basin. CR Geosci 348:333-341. https://doi. org/10.1016/j.crte.2015.11.006

Ronchi A, Sarria E, Broutin J (2008) The "Autuniano Sardo": basic features for a correlation through the Western Mediterranean and Paleoeurope. Bollettino della Società Geologica Italiana 127(3):655-681
Rossi Ph, Durand-Delga M, Cocherie A (1991) Distinction de deux serie sédimentaires d'age carbonifère supérieur en Corse. Comptes Rendu de 1' Academie des Sciences. Paris 3123:443-450

Saddiqi O, El Haimer FZ, Michard A, Barbarand J, Ruiz GMH, Mansour EM, Leturmy P, Frizon de Lamotte D (2009) Apatite fission-track analyses on basement granites from south-western Meseta, Morocco: Paleogeographic implications and interpretation of AFT age discrepancies. Tectonophysics 476(1):29-37. https://doi.org/10.1016/j.tecto.2009.01.007

Schafer A (2011) Tectonics and sedimentation in the continental strikeslip Saar-Nahe Basin (Carboniferous-Permian, West Germany). Zeitschrift der Deutschen Gesellschaft fuer Geowissenschaften 62:127-155. https://doi.org/10.1127/1860-1804/2011/0162-0127

Schaltegger U, Brack P (2007) Crustal-scale magmatic systems during intracontinental strike-slip tectonics: $\mathrm{U}, \mathrm{Pb}$ and $\mathrm{Hf}$ isotopic constraints from Permian magmatic rocks of the Southern Alps, International. J Earth Sci 96:1131-1151. https://doi.org/10.1007/ s00531-006-0165-8

Schenk M, Bayer U, Otto V, Lamarche J, Banka D, Pharaoh T (2002) The Elbe fault system in North Central Europe- a basement controlled zone of crustal weakness. Tectonophysics 360:281-299. https://doi.org/10.1016/S0040-1951(02)00357-8

Schneider JW, Korner F, Roscher M, Kroner U (2006) Permian climate development in the northern peri-Tethys area-The Lodève basin, French Massif Central, compared in a European and global context. Palaeogeogr Palaeoclimatol Palaeoecol 240:161-183. https://doi.org/10.1016/j.palaeo.2006.03.057

Schwab V, Spangenberg E (2004) Organic geochemistry across the Permian-Triassic transition at the Idrijca Valley, Western Slovenia. Appl Geochem 19:55-72. https://doi.org/10.1016/S0883 $-2927(03) 00127-6$

Scotese CR (2001) Atlas of earth history, vol 1. Paleogeography, Paleomap Project, Arlington, TX

Scotese CR Wright N (2018) PALEOMAP paleodigital elevation models (PaleoDEMS) for the Phanerozoic. PALEOMAP Project

Stampfli GM (2000) Tethyan oceans. Geol Soc Lond Spec Publ 173:123. https://doi.org/10.1144/GSL.SP.2000.173.01.0

Stampfli GM, Borel GD (2002) A plate tectonic model for the Paleozoic and Mesozoic constrained by dynamic plate boundaries and restored synthetic oceanic isochrons. Earth Planet Sci Lett 196:17-33. https://doi.org/10.1016/S0012-821X(01)00588-X

Stampfli GM, Kozur HW (2006) Europe from the Variscan to the Alpine cycles. In: Gee DG, Stephenson RA (eds) European Lithosphere Dynamics, 32nd edn. Geological Society, Memoirs, London, pp 57-82

Tartèse R, Boulvais P, Puojol M, Chevalier T, Paquette JL, Ireland TR, Deloule E (2012) Mylonites of the South Armorican Shear Zone: Insights for crustal-scale fluid flow and water-rock interaction processes. J Geodyn 56:86-107. https://doi.org/10.1016/j. jog.2011.05.003

Timmerman MJ (2004) Timing, geodynamic setting and character of Permo-Carbonifereous magmatism in the foreland of the Variscan Orogen, NW Europe. Geol Soce Lond Spec Publ 223:4174. https://doi.org/10.1144/GSL.SP.2004.223.01.03

Vai GB (2003) Development of the palaeogeography of Pangaea from Late Carboniferous to Early Permian. Palaeogeogr Palaeoclimatol Palaeoecol 196(1-2):125-155. https://doi.org/10.1016/S0031 $-0182(03) 00316-X$

Valente A, Borghi A (2000) Tectono-metamorphic evolution of the anthracite-bearing Basin of La Thuile (External Brianconnais Zone). Géologie Alpine 76:151-163

Van Wees JD, Arche A, Beijorff CG, Lopez-Gomez J, Cloetingh SAPL (1998) Temporal and spatial variations in tectonic subsidence in the Iberian Basin (eastern Spain): inferences from automated forward modelling of high-resolution stratigraphy 
(Permian-Mesozoic). Tectonophysics 300(1-4):285-310. https ://doi.org/10.1016/S0040-1951(98)00244-3

Vargas H, Gaspar-Escribano JM, Lopez- Gomez J, Diederik Van Wees J, Cloetingh S, de La Horra R, Arche A (2009) A comparison of the Iberian and Ebro Basins during the Permian and Triassic, eastern Spain: A quantitative subsidence modelling approach. Tectonophysics 474:160-183. https://doi.org/10.1016/j.tecto .2008.06.005

Veevers JJ (2005) Edge tectonics (Trench rollback, terrane export) of Gondwanaland-Pangaea synchronized by supercontinental heat. Gondwana Res 8:449-456. https://doi.org/10.1016/S1342 -937X(05)71147-3

Verati C, Rapaille C, Féraud G, Marzoli A, Bertrand H, Youbi N (2007) ${ }^{40} \mathrm{Ar} /{ }^{39} \mathrm{Ar}$ ages and the duration of the Central Atlantic Magmatic Province volcanism in Morocco and Portugal and its relation to the Triassic-Jurassic boundary. Palaeogeogr Palaeoclimatol Palaeoecol 244:308-325. https://doi.org/10.1016/j.palae o.2006.06.033

Voigt S, Saber H, Schneider JW, Hmich D, Hminna A (2011) Late Carboniferous-Early Permian Tetrapod Ichnofauna from the
Khenifra Basin, Central Morocco. Geobios 44:399-407. https:// doi.org/10.1016/j.geobios.2010.11.008

Wang CY, Zheng R, Hu Z, Zhou Q, Wang J (2009) High-resolution sequences and reservoirs in the Upper Triassic strata of B block in Algeria. Sediment Geol Tethyan Geol 2:P618.13

Weil AB, Gutiérrez-Alonso G, Johnston ST, Pastor-Galan D (2013) Kinematic constraints on buckling a lithospheric-scale orocline along the northern margin of Gondwana: a geologic synthesis. Tectonophysics 582:25-49. https://doi.org/10.1016/j.tecto .2012.10.006

Zanchi A, Zanchetta S, Berio L, Berra F, Felletti F (2019) Lowangle normal faults record Early Permian extensional tectonics in the Orobic Basin (Southern Alps, N Italy). Ital J Geosci 138(2):184-201

Ziegler PA, Stampfli M (2001) Late Paleozoic-Early Mesozoic plate boundary reorganization: collapse of the Variscan orogen and opening of Neotethys. "Natura Bresciana". Ann Mus Civ Sc Nat $25: 17-34$ 